\title{
Dhū Nuwās and the Martyrs of Najrān in Islamic Arabic Literature until 1400 AD
}

\author{
LASSE LØVLUND TOFT \\ Aarhus University, Denmark
}

\begin{abstract}
The last king of Himyar, Yūsuf As'ar Yath’ar (reign 522-525 AD), is famously known as the Jewish persecutor of the Christians of South Arabia, most notably the ones in Najrān, who were martyred in the autumn of $523 \mathrm{AD}$. In Islamic literature, the king was known as Dhū Nuwās and became associated with the aṣhāb al-ukhdūd "the People of the Trench" mentioned in Q85:4-10. The article surveys the Islamic Arabic literature about Dhū Nuwās and the Martyrs of Najrān from its beginnings until the fifteenth century $\mathrm{AD}$, and tries to establish literary relationships between the sources as well as literary typologies in the rich and overwhelming literature. Throughout the survey, attention is given to how different Muslim writers have dealt with the Pre-Islamic 'Abrahamitic' past of Arabia in forming the Islamic narrative of history.
\end{abstract}

KEYWORDS Martyrs of Najrān, Dhū Nuwās, Himyar, People of the Trench, Qur'ānic Exegesis, Islamic historiography, Muslim attitudes towards Pre-Islamic Jews and Christians

\section{The Martyrs of Najrān and Islam-An Introduction}

A century before Muhammad and his community of monotheists migrated from Mecca to Yathrib, at the oasis of Najrān in Southern Arabia, a group of Christians, which had been there since around $450 \mathrm{AD}$, came into conflict with the Himyarite rulers to the South. In 522, the Hiimyarite king Yūsuf As’ar Yath'ar, later known as Dhū Nuwās in the Islamic tradition, initiated military campaigns against those Axumites who were in Yemen and their Himyarite Christian allies who resided in his kingdom and beyond. ${ }^{1}$ The campaigns culminated with the siege of Najrān in 523 and the successive executions of a large number of inhabitants, among whom the city's Christian nobility played an important role in the diverse hagiographical

1 For this complicated history, see Robin (2010, 39-106); Robin (2015, 127-71), among Christian Julien Robin's numerous pioneering contributions. See also Bowersock (2013), for an inviting historical synthesis of the main sources. 
literature that was produced in the aftermath of the events. ${ }^{2}$ The historical circumstances and the cause(s) of Yūsuf's aggressions against South Arabian Christians have been explained in different ways, ${ }^{3}$ but one of the most prominent is the explanation of differing religious, and by extension political, sympathies-Yūsuf was Jewish along with generations of rulers at the Himyarite court before him. ${ }^{4}$ It is exactly this religious difference which the Christian hagiographers latched onto, and they made it the prime motivation of Yùsuf for executing the Christians. With the hagiographical embellishments with which the tradition eventually was adorned, the Christian writers successfully rebooted a mental software of martyrdom and persecution, which had been without major updates since Diocletian and Galerius.

This interesting fact, that a Jewish king in South Arabia had persecuted Christians in PreIslamic times, also caught the imagination of Muslim writers, but for different reasons. From very early on in the development of Qur'ānic exegesis, the events of the persecution and massacre of the Christians of Najrān were associated with the enigmatic sentences in Q85:410, here cited from Arberry's translation:

Slain were the Men of the Pit, the fire abounding in fuel, when they were seated over it and were themselves witnesses of what they did with the believers. They took revenge on them only because they believed in the All-mighty, the Alllaudable, God to whom belongs the Kingdom of the heavens and the earth, and God is Witness over everything. Those who persecute the believers, men and women, and then have not repented, there awaits them the chastisement of Gehenna, and there awaits them the chastisement of the burning.

The episode of the massacre at Najrān came to be reported as an interpretative frame of these Qur'ānic verses in most works of tafsīr (and often the only interpretative frame mentioned). In this sense, the episode was also included in pieces of historiographical literature, such as the Sïra, ${ }^{5}$ as a sabab al-nuzūl, contextualizing the Qur'ān and thereby introducing these Christian Martyrs to the divine prophetical narrative of mainstream Islam. Another reason for the interest in the Christian community of Najrān was that historians of Yemeni descent had developed a particularly strong sense of pride, often coupled with an antiquarian interest in the glorious past of the South Arabian people. ${ }^{6}$ They compiled long lists of dynastic rulers from the different Yemeni kingdoms, and collected native legends and poetry. ${ }^{7}$ In the catalogues on the kings of Himyar, Dhū Nuwās is always mentioned as the șāhib al-ukhdūd, and his involvement with Najrān is recurrent in all the entries on him.

The Islamic incorporation of the narratives in question has for a long time interested Western scholars as sources for historical reconstruction of the Himyarite-Axumite conflict, as sources for the history of monotheism in South Arabia, ${ }^{8}$ or as comparative literary material

2 First and foremost in Syriac, but soon after in Greek, Georgian, Armenian, Arabic and Ge'ez. See Guidi (1881); Moberg (1924); Shahîd (1971), for the main sources in Syriac, and Taylor (2010, 143-76) for a meticulous and good comparative analysis of these. See Detoraki (2007) for the Greek tradition and Bausi \& Gori (2006) for the Arabic and Ethiopic traditions.

3 See Power (2012, 70-75), for a presentation and discussion of the difference hypotheses.

For Judaism in Himyar, see Robin (2004, 831-908).

For a systematic reading of Najrān's role in the Sïra, see Toft "Najran in the Sira" (forthcoming).

For this Yemeni historiographical tradition, see Rosenthal (1968, 158-59); Donner (1998, 223-24).

For an old but thorough study of lists of South Arabian king according to Islamic sources, see von Kremer (1866).

8 So Fell (1881, 1-74, especially 30-34); Shahîd (1979, 67-87); Rubin (2000, 32-51); Rubin (2008, 185-99); Rubin (2010, 239-40); Munt et al. (2015, 443-54). 
preserving older Christian hagiographical and historical narratives. ${ }^{9}$ This research has been fruitful, and especially the research done since 2010 has brought many new insights and gradually introduced different sources to the discussion. Often, however, historians writing about late antique South Arabia refer to the "Islamic tradition" en bloc while referring to relevant individual Christian texts. There can be two reasons for this: either the Islamic texts dealing with the events in question really are a harmonious lot, or the amount of relevant material can seem quite overwhelming to those not Islamicists and Arabicists. It seems that Ibn Hishām's Sïra and al-Tabarī's Ta'rikkh are the main sources when the "Islamic tradition" of the Martyrs of Najrān and Dhū Nuwās are referred to. Though these two are very important sources and two of the most voluminous, they are also the most well-known and readily accessible, which potentially can bias the view of the "Islamic tradition." The historical reconstruction of Dhū Nuwās' reign (Yūsuf As'ar Yath'ar) and his involvement in Najrān have been attempted by Christian Robin (2008, 2010, 2012), using contemporary South Arabian inscriptions as well as Christian and Islamic sources with great success. What follows, on the other hand, is an attempt at presenting the "Islamic tradition" of Dhū Nuwās and the Martyrs of Najrān in its different manifestations.

The purpose of the present article is twofold: Firstly, to gather the Islamic material that pertains to Dhū Nuwās and the Martyrs of Najrān, ${ }^{10}$ and, when possible, (try) to establish the literary relationships between the different Arabic sources. I have been as comprehensive as possible within the limits of this contribution. ${ }^{11}$ I hope that this literary investigation will help to shed light on less studied but interesting sources, thereby providing a more diverse picture of the Islamic tradition on this historical episode. Thus, the article is also meant as a go-to catalogue of Islamic sources to Dhū Nuwās and the Martyrs of Najrān. Secondly, these texts are great examples of the different ways Muslim authors and compilers have dealt with Jews and Christians of pre-Islamic history, and the article will highlight how different narratives and agendas have moulded the stories to serve these narratives.

\section{An Overview of the Sources}

The present article is the result of readings and analyses of 37 Islamic Arabic sources dealing with the topic in question. They cover many of the genres within Classical Arabic prose: historiography, Qur’ānic exegesis, hadìth, commentary on poetry, dictionaries of geography and ethnography, and $a d a b$. The scope of the sources ranges from one sentence (Abū l-Fidā') to whole sections consisting of around ten pages of edited Arabic prose (al-Tabarī). The sources that have been considered cover the whole of Classical Islamic literature from the beginning of the eighth century (Mujāhid (d. 722), al-Ḍaḥhāk (d. 723)) to the fifteenth century (Ibn Khaldūn (d. 1406)). In the bibliography, the reader will find an alphabetically arranged list

$9 \quad$ Pioneered by Axel Moberg: Moberg (1925, 137-50); Moberg (1930); Hirschberg (1939-1949, 321-38); Binggeli (2007, 173-74); Sizgorich (2010, 125-47); La Spisa (2010, 234-36); La Spisa (2017, 318-40).

10 The legends of Dhū Nuwās also include his rise to power by killing the wicked king Lakhnī'a Yanūf dhū Shanātir, and the Himyarite-Axumite narrative does not end with the death of Dhū Nuwās either but comprises the reign of Abraha and Sayf ibn dhì Yazan, among others. For methodological and pragmatic reasons, I have excluded these passages, which also occur in most of the sources dealt with here. The material I am interested in here thus comprises the episodes beginning with Dhū Nuwās' conversion to Judaism and ending with his death. In addition, the different narratives on the introduction of Christianity in Najrān are included for reasons which will become clear.

11 I am quite certain that many more sources, though probably not many new independent ones, exist in the vast Islamic literature, especially within the tafsir-genre. 
of all the sources and the editions used. References to the relevant sections in each work are found in sharp brackets, as well as throughout the article. ${ }^{12}$ Unless stated otherwise, all translations within this contribution are my own. For the sake of overview, I have divided the sources into five groups:

1) The earliest tafsir-traditions

Tafsïr-traditions attributed to Ibn 'Abbās

al-Ḍaḥhāk

Muqātil and Mujāhid

2) The Kings of Himyar-tradition

3) The traditions from Ibn Isḥāq and Ibn al-Kalbī

The Ibn Ishạā-tradition

The Ibn al-Kalbī-tradition

4) Miscellanous historiographical sources

al-Dīnawarī

al-Hamdānī

al-Maqdisī

5) The mainstream tafsïr-tradition

The Șuhayb recension

The Ibn 'Abbās recension

Three of these groups (2, 3 and 5 ) have been established on the grounds of external information, explicit references to sources, and especially of internal textual relationships, i.e. texts transmitting the same textual tradition, albeit with different degrees of variation. Groups 1 (early tafsir) and 4 (historiographies) contain texts which could not easily be directly associated with a specific tradition, or are representative of (otherwise lost) traditions. The traditions of these five groups are by no means isolated. On the contrary, they are all interlinked in some way.

\section{The Earliest tafsïr Traditions}

While the story about Q85:4-10, found most frequently in works of tafsir, is about a young boy (ghulām) and a monk in Najrān, to which we will return, the earliest mufassirūn did not possess the ballast of a long established tradition, and they often offer snapshots of Qur'ānic interpretation in a time before conformity and traditionalism. These commentaries are often concise and implicit, and are therefore often difficult to understand. Whatever the Qurāan was originally referencing to its intended audience, ${ }^{13}$ it is clear from the tafsir-traditions here, however, that Yemen and Najrān were associated with the aṣhāb al-ukhdūd mentioned in Q85:4-10 from very early on.

12 The only source listed in the bibliography that does not contain specific material on Dhū Nuwās and the Martyrs of Najrān is Ibn al-Nadīm, Fihrist.

13 Adam Silverstein has recently made a very convincing argument for viewing Q85:4-10 as an allusion to Daniel 3 with eschatological implications; see Silverstein (2019, 281-323). 


\section{Tafsīr Traditions Attributed to Ibn 'Abbās}

Traditions attributed to 'Abd Allāh ibn 'Abbās (d. 687) deserve some discussion, despite the controversy that surrounds this figure in the scholarship of hadith and tafsir. ${ }^{14}$ The Tafsir of Ibn Wahab al-Dīnawarī (d. 920) ${ }^{15}$ transmits interpretations of Sürat al-Burūj on the authority of Ibn 'Abbās, which are identical with the equivalent passages in the Tanwīr al-Miqbās min Tafsir Ibn 'Abbass. ${ }^{16}$ Some interesting observations will suffice: this is the only tradition of tafsir dealt with here which does not explicitly mention the people of Najrān in connection with Q85:4, i.e. the așhāb al-ukhdūd "the People of the Trench." The people of the Trench is described rather generically as a "group of believers (qawm min al-mu'minin), whom the unbelievers (al-kuffār) killed by means of fire fueled by naphtha, pitch and firewood." There is no mention of Christianity or Judaism, and the Qur'ānic dichotomy between "believers" and "unbelievers" are the only words of religious implications used by 'Ibn 'Abbās.' In the commentary of Q85:10, however, a group from Najrān is mentioned, but as the perpetrators of the believers:

It is said: In this life, where God burned with fire those who were a group from Najrān, some say from the people of Mosul, they seized a group of believers, torturing and killing them with fire in order that they convert to their religion (dinihum). Their king was named Yūsuf, some say Dhū al-Nuwās. So he (God) mentioned the believers, who did not turn away from the belief in face of their torture.

From the presence of the name Yūsuf, it becomes clear that the group of believers is the Martyrs of Najrān. A number of places this text diverts from the main narrative of the tradition, which we will encounter later in the Classical literature. This could suggest that the tafsir tradition is from the time before the tradition about the king of Himyar, Dhū Nuwās and from before his persecution of Christians became common knowledge (mainly informed by Wahb ibn Munabbih (d. 728/732)). First, the mufassir does not explain the obscure word $u k h d u \bar{d}$, which subsequent exegetes explain as a trench, or ditch, that was dug and filled with fire for the Christians, but he remains vague (or ignorant?) about the specific circumstances. Secondly, the victims are not from 'the people of Najrān' (ahl Najrān), but a group of believers who were burned by a group from Najrān (or Mosul ${ }^{17}$ ), who in turn was burned by God as punishment. The mufassir knows Yūsuf by the name of Dhū al-Nuwās, to my knowledge not attested anywhere else, and he is the king of the group of Najrān (see also the tafsìr of Muqātil), not Himyar. These factors point to an early dating of this tafsir tradition of Q85, which also share some features with al-Ḍaḥhāk and Muqātil, even if the Tafsïr as a whole should be dated to the ninth or tenth century. It is of course impossible to determine if it really is the work of Ibn 'Abbās, but it cannot be rejected based on this case reading of commentaries of Q85:4 and 10.

14 Under the Abbasid caliphate, Ibn 'Abbās became a figure of political propaganda, the agents of which produced a great number of pseudepigraphical traditions. This makes most of the hadiths attributed to him very suspicious, since it is very difficult, if not impossible, to determine which traditions are authentically from Ibn 'Abbās. See Goldfeld (1981, 125-35); Berg (2011, 259-83). Ibn Wahab, Tafsir II, 487-488.

Often attributed to al-Fīrūzābādī (d. 1414). See Rippin (1994, 38-83) for a lengthy analysis and discussion of this tafsir, attributed to various people, including Ibn Wahab and al-Fīrūzābādī. Rippin dates it to the ninth to tenth century AD, with some core of the material consisting of earlier traditions (1994, 70-71). This uncertainty about the location is apparently also extant in the anonymous Persian Tafsir-e Qur'ān-e majīd (The Cambridge Anonymous Tafsïr), where Dhū Nuwās is said to be in either Mosul or Najrān! See Cook $(2008,137)$. 


\section{al-Ḍaḥḥāk}

Al-Ḍaḥhāk ibn Muzāhim (d. 723) was part of the first generation of Muslim exegetes and is quoted by numerous later mufassirūn. ${ }^{18}$ It is unclear whether he himself actually produced a coherent work of tafsir, but the traditions attributed to him through quotations in later works have been gathered into a two-volume 'Tafsīr' by Muhammad Shukrī Aḥmad al-Zāwiyyatī. Three different quotations in this work are of interest to us, all commenting on Q85:4. ${ }^{19}$ Quotations 2878 and 2879 give two very similar accounts of the aṣhāb al-ukhdūd, here $2878^{20}$ : "they allege that the People of the Trench are from the banū Isrā'ìl. They seized men and women and dug a trench for them. Then they lit fires in it, put the believers (al-mu'minin) in front of it, and said: 'you shall apostatize (takfirūna) or we will throw you into the fire!.'" Quotation 2879 does not identify the People of the Trench with banū Isrā'ìl, but simple states that "they are a group, who made a trench in the ground." The 'believers' of quotation 2878 are here called "the people of Islam (ahl al-islām)" and are thus exhorted: "deny God (ikfirū bi-lläh) and adhere to our religion!" As we are told, the 'people of Islam' preferred fire to unbelief (al-kufr) and were thrown into the fire. Quotation 2880 again identifies the People of the Trench, who now "were among the Christians of Yemen (kānū min nașārā al-Yaman)," and tells us the event happened forty years prior to the call of Muhammad (mab'ath rasūl Allāh). In quotations 2878-9, al-Ḍhhāk identifies the "People of the Trench" as the perpetrators, not the victims, and if these three traditions attributed to al-Ḍaḥhāk should be read harmoniously, then the Christians, who may or may not be thought of as part of banū Isrā'îl, are here thought of as the perpetrators. The victims, however, are all described with typical Islamic lingo, which was a common way for Muslim authors to 'appropriate' pious individuals (often from the 'People of the Book') who lived in Pre-Islamic times. This will become a recurrent theme in this article.

\section{Muqātil and Mujāhid}

Muqātil ibn Sulaymān's (d. 767) Tafsìr is the oldest extant exegetical work that comments on the Qur'ān in its entirety. ${ }^{21} \mathrm{He}$ is known to have relied on Christian and Jewish informants in his work, which thus contains a great amount of isrā'iliyyāt. ${ }^{22}$ In commenting Q85:4, he identifies the aṣhāb al-ukhdūd with "Yūsuf ibn Dhū Nuwās from the people of Najrān (min ahl Najrān)." ${ }^{23}$ In agreement with both al-Ḍaḥ̣āk and the version attributed to Ibn 'Abbās, the word $a s h \bar{a} b$ is interpreted as the perpetrators, and these are identified with a group or an individual from Najrān. ${ }^{24}$ As was also the case with 'Ibn 'Abbās,' Muqātil gives a variant name of Yūsuf, namely 'son of Dhū Nuwās.' In Muqātil's version, Yūsuf had dug a furrow and burned in it anyone who professed monotheism (man takallama [...] bi-l-tawhid). We are told that there were eighty believing men and nine women among his people, whom he ordered to abandon Islam (an yartaddū 'an al-islām). As the believers deny this, Yūsuf begins to throw them, one after another, into the fire

18 See Versteegh (2011, 279-99), for a study of the al-Ḍaḥhāk and his 'tafsīr.'

19 al-Ḍaḥhāk, Tafsìr, II, 950; nos. 2878-2880.

20 A very similar tradition is given by al-Ṭabarī (d. 923) attributed to Ibn 'Abbās, who on the contrary identifies the People of the Trench with Daniel and his three companions; Jāmi` al-bayān, XXX, 132-133.

21 See Versteegh (1990, 206-42); Koç (2008, 69-101).

22 For comparative evidence, see Mazuz (2016, 497-505).

23 Muqātil, Tafsìr, IV, 647.

24 For Muqātil's material on the delegation of the Christians of Najrān in Medina, and the mubāhala episode, see Nickel (2006, 171-88). 
until a woman passed by with her young boy suckling. When the woman looked at her son, she feared for him, so she turned around. They urged her to apostatize, but she refused. So they beat her until she turned back around, but she kept turning around fearing (for her son) until the boy spoke and said to her: 'Mother, before you is a fire, which will never be extinguished!' When she heard the words of the infant, she was prepared (uhdirat) to throw herself into the fire. God, mighty and great, then placed their souls in heaven (al-janna). ${ }^{25}$

A similar story to the one of Muqātil is found in the Tafsir of Mujāhid ibn Jabr (d. 722) collected by Muhammad 'Abd al-Salām Abū al-Nīl (ed. 1989):

The people of the Trench dug a trench and filled it with fire. They threw into it anyone who believed in God, and let everyone who apostatized be. They had thrown more than eighty believers (in the fire), when they came upon an old woman and her son who followed her, a young boy. When she saw how the fire consumed them, she became anxious and said: 'O my son, do you not see (it)?' Her son said to her: 'Mother, carry on, don't be a hypocrite!' So she carried on and her son jumped in after her. ${ }^{26}$

This story does not give any kind of contextual information. No location, names of persons or religious affiliation is mentioned. In the subsequent quotation, however, Mujāhid says that the ukhdūd was a chasm (shaqq) in the ground in Najrān, in which they used to torture people. $^{27}$

The story about the woman and her son is interesting, and we will encounter it throughout many of the sources, ${ }^{28}$ but it will suffice for the time being to notice that there is still no mention of Jews or Christians (with the exception of al-Ḍaḥhāk's quotation 2880). Muqātil and Mujāhid likewise tell this story through the Qur'ānic religious nomenclature of believers, unbelievers, and Islam, as is to be expected from the specific genre.

\section{The Kings of Himyar Tradition}

The following six texts transmit a tradition which ultimately derives from a very early work of Yemeni origin about the kings of Himyar. This has often been attributed to Wahb ibn Munabbih (d. 728/732), given that a work of this kind is attributed to Wahb by different later Muslim biographers, and that we have a work by Ibn Hishām (d. 833) called Kitāb altijān fi mulük Himyar, in which he transmits a tradition or work by Wahb. There is evidence to suggest, however, that Kitāb al-tijjān is a compilation of two works, one by Wahb and a perhaps earlier anonymous work on the kings of Himyar, but the exact relationship between Wahb

25 Muqātil, Tafsìr, IV, 648.

26 Mujāhid, Tafsìr, 718. The isnād is: 'Abd al-Raḥmān $\leftarrow$ Ibrāhīm $\leftarrow$ Ādam ibn Abī Iyās $\leftarrow$ al-Mubārak ibn Faḍḍāla $\leftarrow$ al-Hassan.

27 Mujāhid, Tafsìr, 718.

28 This episode is found in Christian texts dealing with the martyrs of Najrān as well, namely, the Arabic and Ethiopic versions of the Martyrdom of Arethas (\$22); see Bausi \& Gori (2006). I had originally planned and written an appendix on this and the relationship between the early Islamic traditions and the Christian literature on the Martyrs. I believe that the explanation as to why the Martyrs of Najrān became associated with Q85:4-10 in the first place can be found in the episode of the woman and her speaking infant, when read together with its Christian counterparts and other Christian sources. Due to challenges of space and format, I have split the work into two, and I hope to publish the other part in the near future. 
and Kitāb al-tijān is far from explained. ${ }^{29}$ This tradition has been very important for how later Muslim historians arranged their works, e.g., Ibn Isḥāq's Sïrat Rasul Allāh, ${ }^{30}$ and a significant number of subsequent works contains this tradition. Therefore, I here give a translation of the relevant passage in Ibn Hishām's Kitāb al-tijjān:

Dhū Nuwās Zur'a ibn Tubbān As'ad, a crowned king.

When it reached Himyar what Dhū Nuwās had done, they said to him: "No one is more fitting to be our king than you, since you have delivered us from this evil!" He was the last of the kings of Himyar and he remained in power for some time. He was the master of the Trench (șāhib al-ukhdūd), whom God has mentioned in the Qur'ān, that is, it had reached him [i.e., Dhū Nuwās] concerning the people of Najrān that a man from the house of Jafna of Ghassān had come to them and brought them to the religion of Christianity (fa-raddahum ilā dīni l-nașāniyya). So Dhū Nuwās himself travelled towards them until [he stopped and] dug trenches in the ground and filled them with fire. He then left everyone alone who followed him in terms of his religion, but threw into [the fire] anyone who kept adhering to Christianity. [So he did] until he brought forward a woman with a young boy of seven months. Her son said to her: 'Mother, carry out your religion! It is certainly fire, but there will be no fire after this one!' A man called Dhū Tha'labān by the name of Daws passed by the woman and her son in the fire. He travelled by sea to the king of Abyssinia and told him about what Dhū Nuwās had done to the people of his religion. Then the king of Abyssinia wrote to Qayșar [i.e., the Byzantine Emperor], informing him about what Dhū Nuwās had done, and asking him permission to set out towards Yemen. [The Emperor] wrote to him with his order to march against [Yemen]: He told him that he should conquer it and commanded him to entrust Dhū Tha'labān with the command over his people, and to stay in Yemen with those who were with him. The king of Abyssinia advanced with 70.000 men, so Dhū Nuwās rallied against them and fought with them, but they defeated him and killed many of his people. Defeated, he ran out towards the sea, while they were right behind him. He jumped into it and drowned together with those of his people who were with him. The reign of Dhū Nuwās lasted for 38 years. $^{31}$

This passage is the prose part of the entry on Dhū Nuwās in a list of the kings of Himyar and is of the historical or annalistic genre. Dhū Nuwās is preceded by the wicked king, Lakhī'a ibn Yanūf (dhū Shanātir), whom Dhū Nuwās kills, which is why the people appoint him as their king, and he is followed by king Abraha. Unlike the tafsir pieces presented so far, the Kitāb altijān is interested in specifics-in who, where, what, and when. Even though the association with the Qur'ān is acknowledged, it is not interested in Qur'ānic matters but in the information and legends of the Himyaritic king in question. There is no attempt to appropriate the Martyrs of Najrān as 'proto-Muslims' or as generic 'believers.' They are explicitly Christians, and the origin of this Christianity is given as well: A man from the house of Jafna of Ghassān, i.e., the Arab vassal state of the Byzantine Empire. This tradition seems not to have received

29 On this very complicated issue, see Retsö (2005-2006, 227-36), which also shows how much in need we are of a new critical edition. See also Khoury (1972, 286-302).

30 See Guillaume (1955, XVIII).

31 Ibn Hishām, Kitāb al-tijā̄n, 301. 
much attention in previous studies on the Christianization of South Arabia, which have been primarily concerned with the stories of Faymiyūn and 'Abd Allāh al-Thāmir, dealt with below. These, of course, give actual accounts of Christianization, and there is therefore much more to say about them, but it seems strange not to include this source, given the fact that it is old, and that it mentions a specific tribal (and by implication geographical, political and ecclesiastical) affiliation of the missionary. Curiously, there is no mention of Judaism or any other specific religion of Dhū Nuwās. It simply says that the conversions to Christianity in Najrān were the reason for his aggressive actions against the city, and that he would leave everyone who followed him in terms of his religion ('alā dinihi) alone. It is difficult to determine whether this silence on the specific religion is due to an intentional ambiguity on the author's or Ibn Hishām's part, or due to the poor editorial condition in which we have this text. Yet again, the story of the woman and her son occurs, this time in a slightly more elliptic version.

Ibn Qutayba (d. 889) has transmitted large parts of this tradition of the Himyaritic kings in his Kitāb al-ma'ārif, in which he also states that he used a work by Wahb ibn Munabbih called 'The Book on the Beginnings and the Stories of the Prophets. ${ }^{32}$ The section on Dhū Nuwās follows Kitāb al-tijān relatively closely, ${ }^{33}$ but there are some interesting differences. Beside small textual changes, which I will not comment on here, there are minor differences in content. Ibn Qutayba states explicitly that Dhū Nuwās was an adherent of Judaism. The missionary is not said to come from the house of Jafna, but Ibn Qutayba states that "he came to them prior to the house of Jafna, the kings of Ghassān" (atāhum min qablu āl Jafna mulūk Ghassān). The whole sequence of Dhū Tha'labān and the royal correspondence is almost the same as in Ibn Hishām, but after the death of Dhū Nuwās, Ibn Qutayba gives a short "coda" comprising the reign of Dhū Jadan who suffers the exact same fate as his predecessor. The duration of the reign of Dhū Nuwās is given as 68 years, but it is unclear whether this includes the reign of Dhū Jadan or not.

Unlike Ibn Hishām and Ibn Qutayba, al-Mas'ūì̄ (d. 956), in his Murūj al-dhahab, does not present the section on Dhū Nuwās as part of a list of Himyaritic kings. Rather, he has extracted this passage either from a work by Wahb, whom he lists as an authority at certain places in the chapter, or from Ibn Qutayba, and inserted it into a chapter (chapter 6) on "the people of the interval (ahl al-fatra) between Christ and Muhammad," which is a catalogue of pre-Islamic monotheists. Al-Mas' $\bar{u} d \overline{1}$ is in this passage not interested in Dhū Nuwās, but in the "people of the Trench, ${ }^{34}$ and it is clear that he does not have the same historical/annalistic aims with this passage as his source(s). ${ }^{35}$ Therefore, he has to massage the text in certain places with a prophetic reading. First of all, al-Mas' $\bar{u}$ dī has omitted any mention of a missionary. Furthermore, he has replaced the word 'Christianity' (al-nasrāniyya) with the euphemism 'the religion of Christ' (din al-Masih), which is often used by Muslim authors to refer to the 'uncorrupted' form of monotheism which Jesus brought to his people, who subsequently altered it into the schismatic religion of reality which Muslims refer to as 'Christianity.' It is especially with respect to the woman and her son that al-Mas' $\bar{u} d \overline{1}$ 's interpretative biases come to the foreground. While the premature linguistic abilities of the seven months-old boy are taken for granted by

32 Wahb is cited 48 times in Kitāb al-ma'ārif (Lecomte 1965, 77n1). Ibn Hishām, however, is not mentioned in any of his works (Lecomte 1965, 78), which suggests an alternative line of transmission. On Ibn Qutayba in general, see Lecomte (1965). On the relationship between Wahb and Ibn Qutayba, see Pregill (2008, 215-84, especially 242-258). See also de Prémare (2005, 531-49). Ibn Qutayba, Kitāb al-ma'ārif, 311-312.

Al-Mas' $\bar{u} d \overline{1}$, Murūj al-dhahab, I, 74-75; §129-130.

35 For a study of the historiography of al-Mas'ūìì, see Khalidi (1975). 
Ibn Hishām and Ibn Qutayba, al-Mas' $\bar{u} d \bar{~}$ explains it as a result of divine intervention: “[...] as (the woman) came closer to the fire, she became anxious. So God endowed the infant with speech (fa-antaqa Allāh al-tifl) and it said [...]" It is also worth noting that instead of 'a small boy' (sabī), as in the two earlier works, al-Mas'ūdì has the word 'infant' (țifl) making the miracle even greater. ${ }^{36}$ There can apparently be no room for misunderstanding or ambiguity for al-Mas' $\bar{u} d \bar{i}$, since he makes the following statement after the woman and her son have been thrown into the fire: "the two of them were monotheistic believers, not adherents of the Christianity of that time" (wa-kāna $\bar{a}^{37}$ mu'minayni muwahhidayni lā 'alā dīn al-nașāniyya fi hādha l-waqt). The sequence of the royal correspondence is different from the two sources mentioned so far. In Ibn Hishām and Ibn Qutayba, Dhū Tha'labān first travels to the king of Abyssinia, who then writes to the Byzantine Emperor for permission to intervene. In Murūj al-dhahab, Dhū Tha'labān goes straight to the Emperor, king of the Byzantines (Qayșar malik al-Rūm), as he is called, who then sends his request forward to the king of Abyssinia, now called by his Ethiopian title, the Negus (al-Najāshi), whose kingdom was closer to the area of conflict. This difference is probably due to an influence from the Ibn Ishāq tradition, in which Dhū Tha'labān first travels to the Emperor (Qayșar șāhib al-Rūm ${ }^{38}$ ), who refers him to the Negus, because of the distance between his kingdom and Yemen. Al-Mas' $\bar{u}$ di refers, in connection to this, to two of his own earlier works, ${ }^{39}$ where he dealt with this episode in further detail, as well as the section on the kings of Yemen later in the Murüj, where he unfolds the Axumite-Himyarite conflict. ${ }^{40}$

In 961 AD, Ḥamza al-Iṣfahānī (d. after 961) completed his chronology of pre-Islamic and Islamic dynasties, called Ta'rỉkh sinī mulūk al-arḍ wa-l-anbiy $\bar{a}^{3} .{ }^{41}$ It consists of ten chapters, each giving a list of rulers of the different kingdoms and dynasties. In order, they are: the

36 See the lemma țflun in Lane (1863, vol. 8, vols. 5, 1860): "a new-born child, or young infant [...] or it is applied to a child until he discriminates [...] after which he is called [șabī]."

$37 \quad$ See apparatus note 13.

38 Ibn Hishām, Sïra, I, 25.

39 Called Kitāb akhbār al-zamān and Kitāb al-awsaț. These works have not survived to our times. See $E I^{2}$, "al-Mas'ūdī," by Charles Pellat.

40 I.e., in chapter 43 of the Murūj (II, 199-200; §1006-1008): "Then reigned Yūsuf Dhū Nuwās ibn Zur`a ibn Tubba' the Minor ibn Hassān ibn Tubba' ibn Abī Karib, whose story we have already mentioned in another section of our book, namely, what was of his affair with the people of the Trench, when he burned them with fire. [...] Abyssinia crossed over to him from the ports of Bādịi and al-Zayla', which are (along) the coast of Abyssinia according to the opinion (hasb) we have mentioned, to the ports of Ghallăfiqa by the coast of Zabīd of the land of Yemen. Yūsuf Dhū Nuwās drowned himself after long battles out of fear for shame (al-'āri). His reign lasted for 260 years, though some say much less than that. That was because when the Negus, king of Abyssinia, heard what Dhū Nuwās had done to the followers of Christ, and what he had inflicted upon them of different kinds of torture and burning with fire, he sent Abyssinia over to him with Aryāț ibn Aḍkham in command. He ruled over Yemen for twenty years." It is clear that al-Mas' $\overline{\mathrm{u}} \mathrm{d} \overline{\mathrm{i}}$ has had a different source(s) available for this passage. The mention of specific ports on either side of the Red Sea is something which is only, as far as I am aware, found in the Christian hagiographical tradition; see Martyrdom of Arethas $\$ 29$ and 31, Detoraki (2007, 262-69). See also the Arabic version; Bausi \& Gori (2006, 72-73). Bādịi was located on the island of al-Rīh, just off the coast of modern-day Sudan, north of the Eritrean border; see Power (2012, 166-69). Al-Zayla' can be identified with modern Saylac in Somalia just south of Djibouti. Arabians knew it as a great source of slaves and aromatics; see Power (2012, 18587). For the port of Ghallafiqa near Zabīd on the Yemeni coast, see Power (2012, 64, 85-86, 180-85). See Power $(2012,147)$ for a map of the ports.

41 I have used the old edition of Gottwaldt 1844. The Beirut edition [undated, the date is often given in academic bibliographies as 1961] is much easier to navigate, but it has a number of unfortunate textual mistakes. Collating solely the Dhū Nuwās section with Gottwaldt's edition, the following mistakes appear in the Beirut edition: 1) p. 106, 1. 2: an added preposition bi-in front of yahūd. 2) p. 106, 1. 5: the absence of the preposition fi in front of al-ard. 3) p. 106, 1. 7 and 10: Writing Tha'bān instead of Tha labān. As I 
Persians, the Rüm (which comprises the Macedonians, the Romans, the Byzantines and the Ptolemids), the Greeks, the Copts, the Israelites, ${ }^{42}$ the Arabs of Iraq, the Arabs of Syria, the Arabs of Yemen, Kinda and lastly the Muslim Arabs. He was a native of Iṣfahān in Iran, and from the present work and another work of history of his native city, ${ }^{43}$ we can tell that he was somewhat of a Persian nationalist. ${ }^{44}$ In his eighth chapter on Himyar and the Arabs of Yemen, he gives an account of the reign of Dhū Nuwās, ${ }^{45}$ which shows some peculiar differences from the other texts in this tradition, but it is closest perhaps to the text of Ibn Qutayba. ${ }^{46}$ The most striking difference is that Hamza gives a story about Dhū Nuwās' conversion to Judaism and links him to the Jews of Yathrib:

Dhū Nuwās was the master of the Trench, and he was calling those in Yemen to become Jews (wa-l-dā $\bar{\imath}$ man bi-l-Yaman ilā al-tahawwud). Passing through it, he (once) stopped at Yathrib. Judaism appealed to him (fa-ajabathu al-yahūdiyya), so he became a Jew. The Jews of Yathrib incited him to attack Najrān in order to inflict trials on the Christians in it. They had adopted Christianity from a man who had come to them from the house of Jafna, the kings of Syria (mulūk al-Shām). So [Dhū Nuwās] set out towards them from [Yathrib]. He put them before trenches, which he had dug in the ground and kindled with fires, and then he submersed ${ }^{47}$ into them everyone who remained an adherent of Christianity. He brought this doing upon many of them, and he left [Najrān] and went to the royal residence in Yemen. ${ }^{48}$

Then follows the sequence of Dhū Tha'labān and the royal correspondence, which is in agreement with Ibn Hishām and Ibn Qutayba. Hamza's biased knowledge of warfare (in the form of Persian equestrian warfare) is probably why the king of Abyssinia asks for the Emperor's permission to dispatch horses to Yemen (an yujarrida khaylan ilā l-Yaman), instead of permission to set out towards Yemen (al-tawajjuh ilä l-Yaman), and why he has 70.000 riders (fāris) sent from Abyssinia instead of men, as in Ibn Hishām and Ibn Qutayba. Hamza gives the duration of Dhū Nuwās' reign as twenty years, upon which the reign of Dhū Jadan follows. Here, the text is again very reminiscent of Ibn Qutayba's text. There is no mention, however, of the woman and her son.

cannot find any editorial remarks in the Beirut edition, I prefer Gottwaldt to Beirut, and the references henceforward are to Gottwaldt.

For a study of this section, see Adang (2006, 286-310).

Which is no longer extant. See $E I^{2}$, "Hamza al-Ișfahānī" by Franz Rosenthal.

He, for example, often gives 'Persian dynastic coordinates,' when writing about other dynasties. Introducing Dhū Nuwās, he writes: "After him, Dhū Nuwās took rule during the time of Fīrūz ibn Yazdjird and the period of Qușayy ibn Kilāb." The additional mention of the leader of Quraysh points to the largest and final section of the book, the history of the Muslim Arabs, which of course also links or frames it to the prophetic history. His list of the kings of Himyar does not end with Sayf dhī Yazan, as in Kitāb al-tijāan, but includes also the Persian rulers of Himyar from around 570 onwards.

Hamza, Ta'rikk, 133-134.

Hamza gives references to some of his sources, which unfortunately are quite unspecific. In introducing the chronology of the Yemenite kings, Hamza writes thus: "[...] this [preceding story] is a tale (hikāya) which the Yemenites told about the beginning of their annals (tawārikhihum). I have read in stories (akhbār) which al-Haytham ibn 'Adī attributed to ibn 'Abbās that [...]" (Hamza, ta'rīkh, 122). He has also read in stories (akhbār) transmitted by 'İsā ibn Da’b (ibid. 123), and refers in different places to a "book among the books of the stories of Yemen (kitāb min kutub akhbār al-Yaman)" (ibid., 130, 132).

Reading yugharriqu, or yughriqu (يغرق) instead of ya'rifu/yu'arrifu (يعرف). It is ultimately a corruption from yaqdhifu (يقذف) "throw," which is the verb found in both Ibn Hishām, Ibn Qutayba and al-Mas'ūdī. Hamza, Ta'rikh, 133-134. 
The last two sources in this textual tradition are a lot later. The Andalusian poet and historian, Ibn Sa'īd al-Maghribī (d. 1286), deals extensively with Yemeni folklore and traditions in his Nashwat al-țarab fi ta'rïkh jāhiliyyat al-`Arab. Throughout this work, Ibn Sa'īd quotes explicitly from Kitāb al-tijā̄n ${ }^{49}$ and from Ibn Qutayba, among others. The section on Dhū Nuwās ${ }^{50}$ is close to these two sources. From a text-critical point of view, the text is closest related to Ibn Qutayba's text, but with many sporadic similarities to Ibn Hishām's text. Ibn Sa'īd also has some unique textual features. It omits three sentences contained in the other sources (the mention of digging trenches and filling them with fire; the Emperor's answer commanding the king of Abyssinia to give Dhū Tha'labān command over his people and to stay in Yemen; and finally Dhū Nuwās drowning). ${ }^{51}$ The elliptic list of Himyarite kings in Abū l-Fidā's (d. 1331) Mukhtașar ta'rīkh al-bashar is derived from Hamza al-Ișfahānī and Ibn Sacīì al-Maghribī. ${ }^{52}$

The exact relationships between the different texts in this tradition are hard to sort out, especially in what way al-Mas' $\bar{u} d \bar{i}$ and Hamza relate to the tradition. Figure 1 is an attempt to present the tradition when both internal and external data are considered. ${ }^{53}$

\section{The Traditions from Ibn Isḥāq and Ibn al-Kalbì}

\section{Ibn Ishạāq}

The second tradition about Dhū Nuwās and the Martyrs of Najrān is the most well known, both among Muslim historiographers and in Western scholarship. The Sïrat Rasūl Allāh by Muḥammad ibn Ishāa (d. 767) is famous for being the earliest chronologically systematic presentation of the life of the prophet Muhammad. Among other attestations, it is preserved in large portions through a redaction done by Ibn Hishām (d. 833) and through extensive quotations in the large Ta'rïkh by al-Tabarī (d. 923). In connection to the theme of Najrān, Western scholars have in particular been interested in the two different accounts of the Christianization of Najrān, and in the question of which Christian sources could have been the Vorlagen of the accounts. ${ }^{54}$ The first story of Christianization concerns the pious builder Faymiyūn and his disciple Șâliḥ, and their activities in Syria. It tells of Faymiyūn's powers through prayers and oaths-he kills a seven-headed snake with a curse and heals several sick people through prayer. Faymiyūn and Șāliḥ are then captured by Arabs and taken to Najrān, where they are sold as slaves to different masters. The people of Najrān eventually adopt Faymiyūn's religion after he destroys their object of worship, a tall palm-tree, with a prayer.

The second account deals with a native boy of Najrān called 'Abd Allāh ibn al-Thāmir, who, instead of attending classes with the local sorcerer, is instructed in the laws of Islam by an anonymous man who is harmonized by Ibn Ishāa as Faymiyūn from the first account.

49 E.g., Ibn Sa'̄id, Nashwat al-țarab, I, 151.

$50 \quad$ Ibn Sa'īd, Nashwat al-țarab, I, 156.

51 On a word level, Ibn Sa'īd has, among other minor readings, ahl millatihu "the people of his confession" instead of ahl dinihu "the people of his religion" (Ibn Sa'īd, Nashwat al-tarab, I, 156, 1. 13).

52 Abū l-Fidā', Mukhtașar ta'rīkh al-bashar, 118: "Dhū Nuwās reigned after him. Everyone who did not become a Jew, he threw into a trench blazing with fire. He is called the master of the Trench." See page 116 for references to the works of Hamza and Ibn $\mathrm{Sa}^{\mathrm{i}} \mathrm{i} \mathrm{d}$.

53 Names in bold indicate an extant source. A dotted line indicates a relationship proposed through conjecture.

54 For these studies, see the references given above, footnote 9. The Arabic texts are found in Ibn Hishām, Sira, I, 20-24; and in al-Ṭabarī, Ta'rïkh, II, 919-925. For translations of these accounts, see Guillaume (1955, 14-17); Bosworth (1999, 192-202); Jeffery (1946, 196-200); Moberg (1930, 5-8); La Spisa (2017, 321-26). 


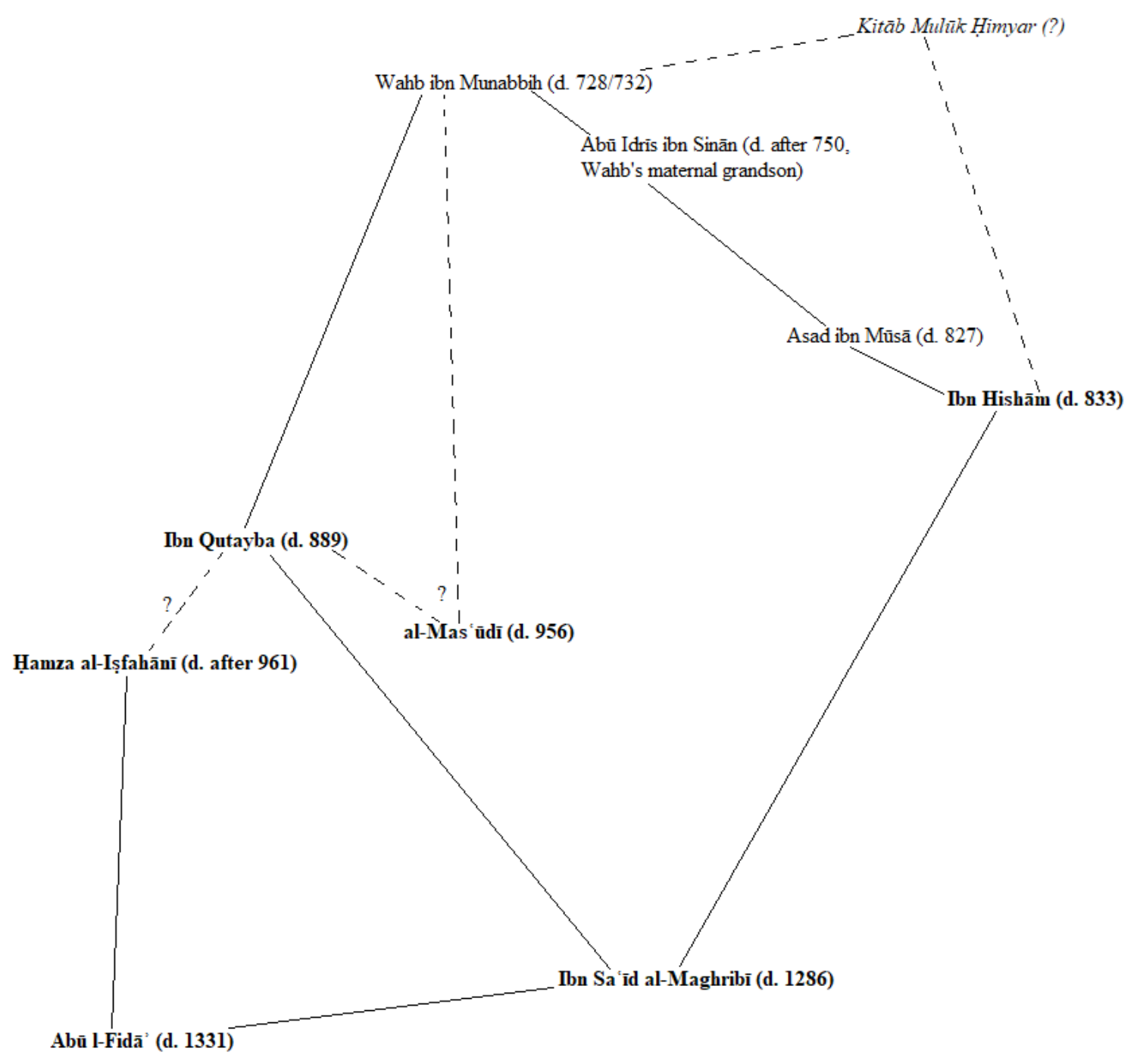

Figure 1 The Kings of Himyar tradition. 
After 'Abd Allāh obtains knowledge of the Great Name of God through his own ingenuity, he initiates a career of converting and healing in Najrān, which attracts the attention of the displeased king, who attempts to execute him. The king only succeeds once he himself acknowledges the unity of God. The people of Najrān accept 'Abd Allāh's religion after the king miraculously drops dead after killing 'Abd Allāh.

The two accounts are attributed to different sources. The Faymiyūn story is told on authority of Wahb ibn Munabbih, ${ }^{55}$ while the story of 'Abd Allāh ibn al-Thāmir is told on authority of Muhammad ibn $\mathrm{Ka}^{\mathrm{c}} \mathrm{b}$ al-Qurazî. While the religion of Faymiyūn is termed the "religion of "İsā ibn Maryam," the religion of "Abd Allāh is described wholly in anachronistic Islamic terms. Both accounts end with Ibn Ishāà's concluding statements that certain 'innovations' came upon the people of Najrān and their religion which were the origin of Christianity (alnașrāniyya) in Najrān. Ibn Ishāāq adds the story of Dhū Nuwās and the Martyrs of Najrān in a surprisingly brief form to the end of the 'Abd Allāh story:

He (i.e., Ibn Ishāāq) related: Dhū Nuwās marched against them with his forces of the Himyarites and the tribes of Yemen. He gathered the people of Najrān together, and summoned them to the Jewish faith, offering them the choice between that and being killed. They chose being killed, so he dug out for them the trench (al$u k h d \bar{u} d)$. He burnt some of them with fire, slew some violently with the sword, and mutilated them savagely until he had killed nearly twenty thousand of them. (Translation by Bosworth $(1999,202))^{56}$

Then follows the sequence of Daws Dhū Tha'labān and the royal correspondence, which is different from the Kings of Himyar narrative, as I mentioned in connection with al-Mas'ūdì's text. Dhū Tha'labān travels directly to the Byzantine Emperor, who issues an order to the Negus about intervention in Yemen, due to the shorter distance between Abyssinia and Yemen. The Negus sends out an army of 70.000 men. Dhū Nuwās tries to rally his forces among Himyar and the tribes of Yemen, but is unsuccessful due to divisions within the Yemenite army. Dhū Nuwās is defeated and drowns himself in the sea. ${ }^{57}$

Apart from Ibn Hishām's redaction of the Sirra, the earliest source, which derives its information from Ibn Ishạā, is the universal history of Aḥmad al-Ya'qūbì (d. 897/905). In his history, al-Ya'qūbī paraphrases the general narrative including the story of 'Abd Allāh ibn al-Thāmir:

King Dhū Nuwās ibn As'ad, whose name was Zur'a, was unruly. He was the master of the Trench, which was (pertaining to the affair that) he was an adherent of the religion of Judaism, and a man called 'Abd Allāh ibn al-Thāmir, who was an adherent to the religion of Christ, had come to Yemen. He proclaimed his religion in Yemen. Whenever he saw a sick or ill person, he said: 'Invoke God for your own sake that he may cure you and you may turn away from the religion of your people!' and [the sick one] would do this, so his followers increased in number.

55 A Syriac text similar to the Faymiyūn-story, titled The History of the Great Deeds of Bishop Paul of Qentos and Priest John of Edessa, was published in 2010; see Arneson et al (2010). The equivalent passages are similar to the point that I would view 'Paul and John' as the source of Wahb ibn Munabbih, although the text has been subject to 'Islamising' redaction at various points by either Wahb or Ibn Ishāq; see Toft (forthcoming) for a close textual comparison between the two texts.

56 Al-Ṭabarī, Ta'rīkh, II, 925. See Ibn Hishām's equivalent passage in Sïra, I, 24.

57 The texts of al-Ṭabarī and Ibn Hishām are very similar, but the former has a few extra details. See al-Ṭabarī, Ta'rïkh, II, 927-928; Ibn Hishām, Sïra, I, 25-26. 
[The news] reached Dhū Nuwās, so he began to search out everyone who professed this religion and to dig the trench in the ground for them. He was burning with fire and killing with the sword until he had annihilated them. So a man among them travelled to the Negus, who was an adherent of the religion of Christianity. The Negus dispatched to Yemen a man called Aryāt with troops against them. They were 70.000 (in number). Together with Aryāt was Abraha al-Ashram among his troops. Dhū Nuwās went out towards him. When they clashed together, Dhū Nuwās was defeated. When he saw the scattered state of his people and their defeat, he beat his horse and jumped with it into the sea. This was the last that was seen of him. The reign of Dhū Nuwās lasted for 68 years. ${ }^{58}$

Even though it is relatively clear that al-Ya'qūbī drew on Ibn Ishạą ${ }^{59}$ for this piece, the relationship is more complicated than it first seems. The overall narrative template into which the Ibn Ishāq material is poured is from a source from the tradition of the Kings of Himyar. The passage is included in a list of kings with the heading "Kings of Yemen," the sequence of the royal correspondence agrees with Kitāb al-tijān and Ibn Qutayba, and the duration of Dhū Nuwās' reign is given as 68 years in agreement with Ibn Qutayba. This harmonization of sources is probably also why 'Abd Allāh is presented as a missionary who 'had come to Yemen,' as is the case with the missionary from the house of Jafna, instead of a native Najrāni boy, as in Ibn Ishāa. The exact identity of this 'Kings of Himyar source,' which has provided the skeleton for al-Ya'qūbì, is uncertain.

Gradually, Muslim authors became less creative, but more rigid/faithful in transmitting the material from Ibn Ishāa. Thus, Yāqūt (d. 1229) relates the accounts according to Ibn Hishām very faithfully, ${ }^{60}$ and later Ibn Kathīr (d. 1373) does the same. ${ }^{61}$ The version according to al-Tabarī is transmitted by Ibn al-Athīr (d. 1232), ${ }^{62}$ and later more loosely in Ibn Khaldūn (d. 1406). ${ }^{63}$ Al-Qazwīnī (d. 1283) transmits an abridged version of the story of 'Abd Allāh ibn al-Thāmir (corrupted to al-Nāmir), who is called "Master of the martyrs of Najrān" (sayyid shuhadā̄ Najrān). ${ }^{64}$

\section{Ibn al-Kalbì}

In juxtaposition to the material of Ibn Ishâa, al-Ṭabarī transmits the story as it is witnessed by Hishām ibn Muhammad al-Kalbī (d. 821), generally known as Ibn al-Kalbī. ${ }^{65}$ It contains some

58 Al-Ya'qūbī, Ta'rīkh, I, 225-226.

59 Al-Ya'qūbī knew and used Ibn Isḥāq material through the Ibn Hishām redaction, which is clear from the introductory statements in the second volume of his history; see al-Ya'qūbī, Ta'rỉkh, II, 3-4. Unfortunately, the text is fragmentary in the beginning of volume one, where general information about the sources used for the pre-Islamic part perhaps would have been.

60 Yāqūt, Kitāb Mu'jam al-Buldān, IV, 752-755. For the sources of this work, see Heer (1898). For the passages in question, see Heer $(1898,6)$.

61 Ibn Kathīr, Al-bidāya wa-l-nihāya, III, 133-136.

62 Ibn al-Athīr, Al-kāmil fi l-ta'rïkh, I, 425-429. For evidence of the reliance on al-Ṭabarī, consider the beginning of the work (I, 3): "I have begun with the great history, which Imam Abū Ja'far al-Ṭabarī composed, since it is the book relied upon with respect to everything, and referred to with respect to the variety. I have taken what is in it from all its paragraphs. I have not forsaken even one paragraph from it."

63 Ibn Khaldūn, Ta'rïkh, II, 68-69.

64 Al-Qazwīnī, Kitāb Āthār al-bilād, II, 84. Whether al-Qazwīnī derives this account from Ibn Hishām or alTabarī is unclear.

65 For Ibn al-Kalbī, see Shahîd (1984, 349-66); and Shahîd (1989, 233-42). Ibn al-Nadīm attributes many works to Ibn al-Kalbī, including a "Book of the Tubba' Kings of Yemen" (kitāb mulük al-Yaman min alTabābica) (Ibn al-Nadīm, Fihrist, I, 303). 
major deviances from Ibn Ishāa. I quote here in full the relevant passages from Bosworth's translation:

As for Hishām b. Muhammad, he says that the royal power in Yemen was handed down continuously, with no one venturing to contest it until the Abyssinians (alHabashah) seized control of their land in the time of Anūsharwān. He related: The reason for their conquest was that Dhū Nuwās the Himyarite exercised royal power in Yemen at that time, and he was an adherent of the Jewish faith. There came to him a Jew called Daws from the people of Najrān, who told him that the people of Najrān had unjustly slain his two sons; he now sought Dhū Nuwās's help against them. The people of Najrān were Christians. Dhū Nuwās was a fervent partisan of the Jewish faith, so he led an expedition against the people of Najrān, killing large numbers of them. A man from the people of Najrān fled and in due course came to the King of Abyssinia. He informed the king of what the Yemenis had committed and gave him a copy of the Gospels partly burned by the fire. The King of Abyssinia said to him: "I have plenty of men, but no ships [to transport them], but I will write to Qayșar (i.e., the Byzantine Emperor) asking him to send me ships for transporting the soldiers." Hence he wrote to Qaysar about this matter, enclosing the [partly] burned copy of the Gospels, and Qayșar dispatched a large number of ships.

$[\ldots]$

As for Hishām b. Muhammad, he asserts that when the ships sent by Qayṣar reached the Najāshī, the latter transported his army by means of them, and the troops landed on the coast of al-Mandab. He related: When Dhū Nuwās heard of their approach, he wrote to the local princes (maqāwil) summoning them to provide him with military support and to unite in combating the invading army to repel it from their land. But they refused, saying, "Let each man fight for his own princedom (maqwalah) and region." When Dhū Nuwās saw that, he had a large number of keys made, and then loaded them on to a troop of camels and set out until he came up with the [Abyssinian] host. He said: "These are the keys to the treasuries of Yemen, which I have brought to you. You can have the money and the land, but spare the menfolk and the women and children." The army's leader said, "I will write to the king," so he wrote to the Najāshì. The latter wrote back to the leader ordering him to take possession from the Yemenis of the treasuries. Dhū Nuwās accompanied them until, when he brought them into Șan'ā', he told the leader, "Dispatch trusted members of your troops to take possession of these treasuries." The leader divided up his trusted followers into detachments to go and take possession of the treasuries, handing over the keys to them. [Meanwhile,] Dhū Nuwās's letters had been sent to every region, containing the message "Slaughter every black bull within your land." Hence they massacred the Abyssinians so that none were left alive except for those who managed to escape.

The Najāshī heard what Dhū Nuwās had done and sent against him seventy thousand men under the command of two leaders, one of them being Abrahah alAshram. When they reached Șan' $\overline{\mathrm{a}}$ ) and Dhū Nuwās realized that he had not the strength to withstand them, he rode off on his horse, came to the edge of the 
sea amd [sic] rushed headlong into it; this was the last ever seen of Dhū Nuwās. (Translation by Bosworth (1999, 204-5, 211-12)). ${ }^{66}$

There are great differences between Ibn Isḥāq and Ibn al-Kalbī, which is also why al-Ṭabarī quotes from them both supplementing each other. The motive of Dhū Nuwās' aggression against the people of Najrān is here one of revenge. The Christians of Najrān have killed two Jewish boys, and the zealous Dhū Nuwās avenges them by raiding (ghazā) the Christians and killing them in large numbers. The sequence of the royal correspondence is also in the reverse order as in the Kings of Himyar tradition.

This version of the story is also found in the commentary to Nashwān ibn Sa'īd al-Himyarī's (d. 1177) poem on the kings of Himyar. It sets the setting with the statement that a civil strife ${ }^{67}$ had broken out in Najrān between Jews and Christians: "A Jew of Najrān complained to him (Dhū Nuwās) about the superiority (ghalaba) of the Christians, as there was a civil strife (fitna) going on between the Jews and the Christians in Najrān. So Dhū Nuwās set out with the army towards Najrān." 68 Nashwān's version follows the one in Ibn al-Kalbī closely, including the incident of the trick with the keys to the treasuries and the two different military expeditions from Abyssinia. The fact that Nashwān was a noble Yemenite living near Șan(ā') giving him access to native sources, suggests that his account is transmitted not directly through Ibn al-Kalbī. ${ }^{69}$ This suggestion is also supported by numerous details in Nashwān's text which are not found in Ibn al-Kalbī: The anonymous man who flees to Abyssinia in Ibn al-Kalbī is identified in Nashwān's text as Dhu Tha'labān, where he does not flee, but is enraged because of what Dhū Nuwās had done to his fellow religionists, and therefore goes to Abyssinia to rally support. ${ }^{70}$ The army leader of the first expedition is named Kālib, or Barbakī, who is sent to

$66 \quad$ Al-Tabarī, Ta’rīkh, II, 925-926, 929-930.

67 This theme of a civil strife in Najrān between Jews and Christians is also echoed in a tradition in al-Ṭabarī's exegetical work Jāmi' al-bayān 'an ta'wil al-Qur'ān (XXX, 132): "Bashar related from Yazīd from Sa'īd on authority of Qatāda that 'Alī ibn Abī Țālib [...] was saying: 'They (the people of the Trench) were people in the towns of Yemen, whose believers and unbelievers were fighting with each other (iqtatala). The believers (of Yemen) overcame the unbelievers. They fought a second time. But the believers overcame the unbelievers (again), so some of them pledged and made agreements not to betray each other. But the unbelievers betrayed them and seized them. Then a man of the believers said to them: 'What is in it for you that you light a fire and put us in front of it? Everyone who follows you according to your religion, that is the ones you will want (to have). Everyone who does not (follow you), will jump into the fire, and you will be rid of them.' Then they started a fire and put (them) in front of it. Their leaders then began to jump into it. An old woman among them remained behind as if she was withdrawing. So an infant in her lap said to her: "Mother, go on, do not be a hypocrite!" God has narrated to you their report and their story."

68 Nashwān ibn Sa ${ }^{i} \mathrm{i} d$ al-Ḥimyarī, Mulūk Hịmyar wa-'aqyāl al-Yaman, 147-149. The translated sentences are found on page 148 .

69 Even though Nashwān quotes from Ibn al-Kalbī (see Mulūk Himyar wa-'aqyāl al-Yaman, page 83, 90 and 175), it is a fairly rare source in the commentary. Wahb ibn Munabbih, however (through Ibn Hishām $\leftarrow$ Asad $\leftarrow$ Abū Idrīs), is quoted extensively (e.g., page 67, 87, 88 and 107). Al-Hamdānī and his al-Iklīl is probably the most frequent authority, though (e.g., page 61, 102, 138, 159, 161 and 162), and given that we do not have the book, which narrates the story of Dhū Nuwās, I will make the cautious suggestion that Nashwān transmits al-Hamdānī's material on Dhū Nuwās, who in turn could have drawn from either Ibn al-Kalbī or from some common lost Yemenite source, which must have contained alternative traditions on the Himyarite-Axumite conflict.

70 Dhū Tha'labān's rage is also mentioned in another of Nashwān's writings, i.e., his dictionary Shams al-‘ulūm. In the entry on the root th - $c_{-} l-b$, Nashwān tells us that Dhū Tha'labān was son of one of the kings of Ḥimyar, called Nawf ibn Sharaḥbīl ibn al-Ḥārith Dhū Tha'labān (Nashwān ibn Sacīd al-Ḥimyarī, Shams al-'ulūm, 15). Apart from this entry, the story of Dhū Nuwās and the Christians of Najrān is repeatedly 


\begin{tabular}{|c|c|c|c|c|c|c|c|}
\hline & Christianization & $\begin{array}{l}\text { Reason for } \\
\text { aggression }\end{array}$ & $\begin{array}{l}\text { Manner of Dhū } \\
\text { Nuwās' } \\
\text { aggression }\end{array}$ & $\begin{array}{l}\text { Royal } \\
\text { correspondence }\end{array}$ & $\begin{array}{l}\text { Abyssinian } \\
\text { army }\end{array}$ & $\begin{array}{l}\text { Death of Dhū } \\
\text { Nuwās }\end{array}$ & $\begin{array}{l}\text { Other } \\
\text { characteristics }\end{array}$ \\
\hline $\begin{array}{l}\text { Kings of } \\
\text { Himyar }\end{array}$ & $\begin{array}{l}\text { Man from the house of } \\
\text { Jafna, the kings of } \\
\text { Ghassān }\end{array}$ & $\begin{array}{l}\text { Conversion to } \\
\text { Christianity }\end{array}$ & $\begin{array}{l}\text { Travels (sāra) to } \\
\text { them, digs trenches } \\
\text { and burns them }\end{array}$ & $\begin{array}{l}\text { Daws Dhū } \\
\text { Tha' labān goes to } \\
\text { the Negus, who } \\
\text { asks the Emperor } \\
\text { for permission to } \\
\text { intervene }\end{array}$ & $\begin{array}{l}\text { Abyssinian king } \\
\text { with } 70.000 \text { men }\end{array}$ & Drowning & $\begin{array}{l}\text { The woman and her } \\
\text { speaking infant }\end{array}$ \\
\hline Ibn Ishāa & $\begin{array}{l}\text { Faymiyūn/ } \\
\text { 'Abd Allāh ibn al- } \\
\text { Thāmir }\end{array}$ & $\begin{array}{l}\text { Conversion to } \\
\text { Christianity }\end{array}$ & $\begin{array}{l}\text { Travels (sära) to } \\
\text { them, digs the trench, } \\
\text { burns some, slays } \\
\text { some with sword. } \\
\text { Kills nearly } 20.000 \\
\text { people }\end{array}$ & $\begin{array}{l}\text { Daws Dhū } \\
\text { Tha' labān goes to } \\
\text { the Emperor, who } \\
\text { orders the Negus to } \\
\text { intervene }\end{array}$ & $\begin{array}{l}70.000 \text { men with } \\
\text { Aryāt in } \\
\text { command }\end{array}$ & Drowning & - \\
\hline $\begin{array}{l}\text { Ibn al- } \\
\text { Kalbī }\end{array}$ & - & $\begin{array}{l}\text { Revenge: 'Civil } \\
\text { strife' between } \\
\text { Christians and } \\
\text { Jews }\end{array}$ & $\begin{array}{l}\text { Raids (ghaza) them } \\
\text { and kills large } \\
\text { numbers of them }\end{array}$ & $\begin{array}{l}\text { A man from } \\
\text { Najrān goes to the } \\
\text { Negus who asks } \\
\text { the Emperor for } \\
\text { help }\end{array}$ & $\begin{array}{l}\text { The first army is } \\
\text { deceived and } \\
\text { killed. Second } \\
\text { army consists of } \\
70.000 \text { men with } \\
\text { two commanders, } \\
\text { Abraha being one }\end{array}$ & Drowning & $\begin{array}{l}\text { Burned Gospel } \\
\text { copy; dispatchment } \\
\text { of ships from the } \\
\text { Emperor; the trick } \\
\text { with the keys to the } \\
\text { treasuries }\end{array}$ \\
\hline
\end{tabular}

Figure 2 Table with narrative typology.

Yemen by the Negus with an army of 30.000 men. ${ }^{71}$ On the other hand, Nashwān does not transmit certain passages extant in Ibn al-Kalbī, such as the involvement of the Emperor and the burned Gospel book.

Textual and literary relationship can be established from external information, explicit references to sources and/or internal textual and narrative differences/similarities. When no explicit reference or external information exists, internal differences and similarities are the only way to associate a specific source with a larger textual tradition. So far, the narrative characteristics of the three different textual traditions can be described as follows in the table in figure 2 , which can serve as a checklist for future sources.

Let us put the table in figure 2 to the test. Ibn Habīb (d. 859) was a student of Ibn al-Kalbīi, ${ }^{72}$ and in his Kitāb al-muhabbar he included a section on the kings of Himyar on the authority of Ibn al-Kalbī. ${ }^{73}$ The passage on Dhū Nuwās, however, also contains material found in Ibn Ishạā:

So Zur'a Dhū Nuwās jumped on him (i.e., Dhū Shanātir) and killed him. He became king after him. Then he became a Jew and he professed Judaism, and called the people to it. He was only pleased with people (who professed) Judaism, otherwise (they would suffer) execution. He was named Yūsuf and was the master of the Trench. He dug trenches in Najrān and lit them with fire. He called its people to Judaism. They were inheritors of a religion of the religion of 'İsā, God bless him.

summarized in the entries on $k h-d-d[u k h d \bar{u} d]$ (page 31), $n-w \smile s$ [Dhū Nuwās] (page 106-107), and $y-z-n$ [Dhü Yazan] (page 116).

71 A confusion between the army leader and the Negus himself is probably the reason why the name of Kaleb, the historical Axumite king, is given as the name of the army leader. In the Syriac work, Book of the Himyarites, Kaleb himself invades Yemen and dethrones Dhū Nuwās, who is in this work called Masrūq. See Moberg (1924).

72 For Ibn Habīb and his work, sources, etc., see Lichtenstädter (1939, 1-27). See also Tayyara (2018, 392416).

73 Ibn Habīb, Kitāb al-muhabbar, 364. 
When they refused this, he threw them into the fire, burned the Gospel, and killed about 20.000 of them with the sword, apart from those he burned with fire, or savagely punished. Because of this, the Abyssinians came to Yemen, for it had reached them what he had done to the Christians. When Dhū Nuwās attacked the Abyssinians, his troops were scattered. He headed (ictarada) to the sea on his horse and drowned (himself) out of fear of being captured. This was the last that was seen of him. ${ }^{74}$

Textually, a passage in Abū l-Faraj al-Ișfahānī’s (d. 967) Kitāb al-aghānī̄75 shows signs of belonging to a similar stream of transmission as Ibn Habīb. ${ }^{76}$ Al-Ișfahānī tells us that Dhū Nuwās raided (ghazā) the people of Najrān and besieged them. He burned the people in trenches for not adopting Judaism, burned the Gospel and tore down the church ( $b i^{`} a$ ) in Najrān. The sequence of Dhū Tha'labān and the royal correspondence is similar to Ibn Ishạa's's version: Dhū Tha'labān shakes off his pursuers through the sandy desert and rides to the Emperor, who refers him to Abyssinia. Al-Ișfahānī includes three speeches: one by Dhū Tha'labān (about the humiliation of the Arabs when they find themselves trampled underfoot by the black Abyssinians due to their different skin-color and traditions), one by the king of Abyssinia as he dispatches an army of 70.000 men and an elephant (commanding Aryāt to kill a third of the Yemenite men, etc., as in al-Ṭabarī's version of Ibn Isḥāq), and one by Aryāṭ (delivering a speech $^{77}$ of encouragement to his forces). At the end of the paragraph, al-Ișfahāni gives an account of the suicide of Dhū Nuwās which resembles the account of Ibn Habīb closely: "They (the Himyarite army) were defeated in every respect. When Dhū Nuwās was taken by fear of being captured, (he made) his horse gallop, and (riding) on it the sea appeared (ista'rada). He said (to himself): 'Death in the sea is better than the captivity of the black!" "78

What do we make of this? Apart from the inclusion of the burned Gospel, the accounts of Ibn Ḥabīb and al-Iṣfahānī certainly bear more resemblance to Ibn Isḥāq's version than to Ibn al-Kalbī's, as it is contained in al-Ṭabarī. The fact that Ibn Habīb explicitly draws his material from his teacher suggests that Ibn al-Kalbī transmitted more than one tradition about Dhū Nuwās and the Abyssinian conquest of Yemen ${ }^{79}$ in the course of his prolific career. ${ }^{80}$ It is quite likely that Ibn al-Kalbī transmitted traditions from Ibn Ishạa in addition to the narrative later transmitted by al-Ṭabarī.

Figure 3 presents my view of the mutual relationships in the tradition family of Ibn Ishāāq/Ibn al-Kalbī. ${ }^{81}$

74 Ibn Habīb, Kitāb al-muhabbar, 368

75 Abū l-Faraj al-Ișfahānī, Kitāb al-aghānī, XVII, 303-304.

76 Unfortunately, the present section in Kitāb al-aghāni (no. 311) was not subjected to source analysis by Fleischhammer (2004, 204). However, Ibn al-Kalbī was a frequent source for Kitāb al-aghānī (Fleischhammer 2004, 87-88, 121). The passage is given as an introduction to a poem by Umayya ibn Abì 1-Ṣalt on Sayf ibn Dhī Yazan and the Persian conquest of Yemen; see Kilpatrick $(2003,265)$.

77 A similar speech was also found in the Book of Himyarites, according to the extant table of contents, where a commander-in-chief by the name of Z'WNS addresses his army upon landing on the shores of Yemen; see Moberg (1924, 6.civ).

78 Abū l-Faraj al-Ișfahānī, Kitāb al-aghāni, XVII, 304.

79 Consider also that a work by the title "The Book of Yemen and the affair of Sayf" (Kitāb al-Yaman wa-'amr Sayf) is attributed to him, Ibn al-Nadīm, Fihrist, I, 304.

80 More than 150 works are ascribed to him (Shahîd 1984, 350). See Ibn al-Nadīm, Fihrist, I, 301-307.

81 Fat lines indicate the transmission of the version of Ibn al-Kalbī. Al-Dīnawarì, al-Maqdisī and al-Hamdānì will be dealt with in the following paragraph. 


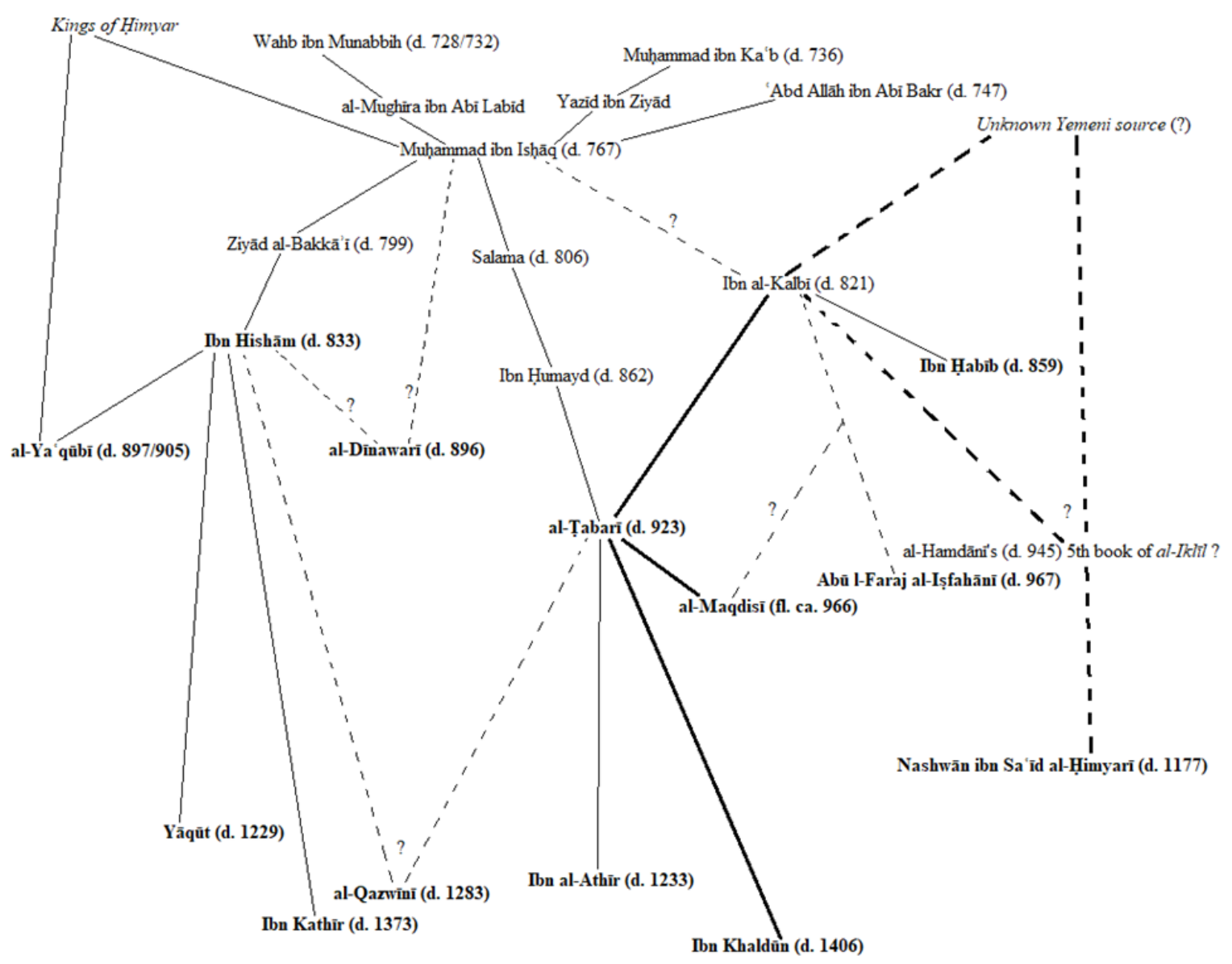

Figure 3 The tradition of Ibn Isḥāq/Ibn al-Kalbī. 


\section{Miscellaneous Historiographical Sources}

Apart of the sources, which can more or less easily be put into connection with one of the three textual strains of tradition, there are a couple of historiographical sources which are more difficult to associate with any one tradition. ${ }^{82}$

\section{al-Dīnawarī}

Of all the texts dealt with in the present article, the universal history Kitāb al-akhbār al-tiwāl by al-Dīnawarī (d. 896) ${ }^{83}$ is the source to which it is hardest to find an equivalent. Apart from having the same antagonists, it deviates on so many points from the other narratives:

They said: In the reign of Qubādh ibn Fīrūz, Rabī̄a ibn Nașr the Lakhmite died, so sovereignty returned to Himyar. ${ }^{84}$ Dhū Nuwās took rule over them, (he) whose name was Zur'a ibn Zayd ibn Ka'b Kahf al-Ẓulm ibn Zayd ibn Sahl ibn 'Amrū ibn Qays ibn Jusham ibn Wā'il ibn 'Abd Shams ibn al-Ghawth ibn Jadār ibn Qațan ibn 'Arīb ibn al-Rā'ish ibn Ḥimyar ibn Saba' ibn Yashjab ibn Ya'rub ibn Qaḥtān, but he was called Dhū Nuwās because of a lock of hair that was dangling (kānat tanūsu) from his head.

They said: In the land of Yemen, Dhū Nuwās had a fire, which he and his tribe were worshipping. From this fire, a portion (lit. "a neck") was extending outwards, reaching a measure of three parasangs, and then returning to its place. Then some of the Jews in Yemen said to Dhū Nuwās: "O king, verily your worship of this fire is vain. If you professed our religion, we would extinguish it with the help of God so that you will learn that you are at risk because of your religion. He agreed with them to adopt their religion if they extinguished it. When this portion (of fire) went out, they brought out the Torah, opened it and began to recite it, and the fire diminished until it ended up in the house in which it was. They did not cease reading the Torah aloud until it was extinguished. So Dhū Nuwās became Jewish and called upon the people of Yemen to adopt (Judaism), and he killed whoever refused. Then he travelled to the city of Najrān to make those of the Christians in it Jews. In it, there was a tribe adhering to the religion of Christ (din al-Masih), which had not been changed, and he called upon them to renounce their religion and adopt Judaism, but they refused. So he ordered that their king, whose name was 'Abd Allāh ibn al-Thāmir, be beheaded by sword. Then he was brought within

82 An additional source should briefly be mentioned despite its lack of mention of Dhū Nuwās or the Martyrs. In the year 1226-1230 AD, the businessman, Ibn al-Mujāwir, was travelling from Khurasan in NorthEastern Iran to Hijāz, Yemen and Oman visiting many places along the way. He wrote his descriptions of places and people and reflections down in his travelogue Tärïh al-mustabșir. He gives certain ethnographic details about Najrān of his time and associates the famous "people of the Trench" with the city without giving any detail (Ibn al-Mujāwir, Tārīkh al-mustabșir, II, 209). Furthermore, he gives a very brief account about the Abyssinians' invasion of Yemen, where "one of the Arabs" extended a chain into the sea (Ibn al-Mujāwir, Tārïkh al-mustabșir, I, 95-96). For a complete English translation, see Smith (2008). The chain is interestingly also mentioned in the Greek Martyrdom of Arethas (§32-33; Detoraki 2007, 269-71) and South Arabian inscriptions (Beeston 1985, 1989). There is not consensus on the exact interpretation of "chain."

83 An English translation of the pre-Islamic passages is found in Bonner (2014, 300-420).

84 Previously in the work, we are told that Himyar fell under Lakhmite rule for a short period of time (alDīnawarī, Kitāb al-akhbār al-țiwāl, 55-56). 
the wall of the city, and seized upon it. ${ }^{85} \mathrm{He}$ dug trenches for the ones remaining and burned them in them. They were the People of the Trench, of whom God tells (may his name be exalted) in the Qurāan. Daws dhū Tha labān escaped and travelled to the king the Byzantines and told him what Dhū Nuwās had done to the people of his religion: killing the bishops, burning the Gospel and razing the churches. So he wrote to the Negus, king of the Ethiopians, and he sent Aryât with a great army. He travelled by sea until he got out on the shore of 'Adan. Dhū Nuwās went towards him and fought him, and Dhū Nuwās was killed. So Aryāṭ entered Șan( $\bar{a}$ ' $[\ldots]^{86}$

It has been suggested that this passage is, among others in al-Dīnawarī, reliant on Ibn Ishạa ${ }^{87}$ It does show features which are either similar to the account in Ibn Ishāa, or have been adapted for other purposes: Al-Dīnawarī mentions the 'Christianity' in Najrān as an unchanged monotheistic religion, and Daws Dhū Tha'labān goes directly to the Emperor, not to the Negus. On these two points, the text fits the account of Ibn Ishāa. However, al-Dìnawari gives a different account on almost all other points of the narrative: Dhū Nuwās is appointed by the Persian king Qubādh (Kavad I); 'Abd Allāh ibn al-Thāmir is the king of Najrān and is beheaded by Dhū Nuwās; Al-Dīnawarī says that Dhū Nuwās killed bishops, burned the Gospel and tore down churches (which resembles the account in Kitāb al-aghāni); and Dhū Nuwās does not drown himself in the sea as all other accounts tell us, but is killed in battle against the Abyssinians.

Al-Dīnawarī clearly told his history from a Persian perspective, which is probably why Dhū Nuwās is put in close connection with the Sassanid Empire, and why he has Dhū Nuwās worship a giant fire in a temple (bayt). It is true that the conversion story has close affinities to an account in the Sira, but there it is in connection with king Tubba' Abū Karib As'ad, where two rabbis convert the people of Yemen through an ordeal by fire. ${ }^{88}$ The decapitation of 'Abd Allāh could maybe be reminiscent of Dhū Nuwās' decapitation of Lakhnī'a Dhū Shanātir, ${ }^{89}$ but again, the differences are major and too many to simply ascribe the passage in al-Dīnawari to Ibn Isḥāq.

\section{al-Hamdānī}

We unfortunately only have the next source in fragments. Only four (nos. I, II, VIII and X) out of ten books of the Iklï by the great South Arabian scholar, al-Hamdānī (d. 945), ${ }^{90}$ are extant. We can tell from the table of contents in book VIII that the fifth book dealt with Yemenite

$85 \quad$ I.e., thumma udkhila fi sūr al-madina fa-dumma 'alayhi. It is not clear what the object of this sentence is (Dhū Nuwās or 'Abd Allāh?), which also makes the meaning a bit obscure.

86 Al-Dīnawarī, Kitāb al-akhbār al-țiwāl, 62-63.

87 Bonner claims that al-Dīnawarì used Ibn Ishāa for much of the material on pre-Islamic Arabia (2015, 5759). Al-Dīnawarī cites the figure of 'Ubayd ibn Sharya al-Jurhumī's Akhbār 'Ubayd (Bonner 2015, 44-45), which is extant as an appendix to the edition of Kitāb al-tijān (Ibn Hishām, Kitāb al-tijān, 311-489). The historicity of this person is contested, see $E I^{2}$, "Ibn Sharya" by Franz Rosenthal. See Crosby (2007) for a translation and study of this text. As Ibn Sharya does not mention Dhū Nuwās or Najrān in the work that has survived, it is of course the safest bet to attribute this material to Ibn Ishāa, but it does not seem as if Bonner has read the texts in synopsis; see, e.g., the false statement in footnote 274 (Bonner 2015, 58), which is debunked by Bonner's own translation of the passage (Bonner 2014, 367).

88 Ibn Hishām, Sīra, I, 17.

89 Ibn Hishām, Sïra, I, 19-20.

90 See $E I^{2}$, "al-Hamdānī," by Oscar Löfgren. For an English translation of the eighth book of the Iklïl, albeit in an incomplete form, see Faris (1938). 
history from As'ad Tubba' up until the time of Dhū Nuwās, ${ }^{91}$ but we can only speculate about what tradition this volume contained and hope that it will be discovered in the future. ${ }^{92}$ There are, however, two passages in the eighth book which deal with the Dhū Nuwās episode. In a list of tombs of legendary persons, the story of the discovery of the tomb of 'Abd Allāh ibn alThāmir is found, ${ }^{93}$ which is quite similar but not identical with the one narrated by Ibn Ishāq on the authority of 'Abd Allāh ibn Abī Bakr. ${ }^{94}$ Enveloped in al-Hamdānī's account, is a short narration of the events in Najrān: "this man was one of those who believed in the disciples of Jesus. His companions were burnt to death by the king of al-Yaman in 'the fire of the ditch,' referred to by God in His book where He says, [...]. 'Abdullāh ibn-al-Thāmir, however, was killed and buried without being mutilated [or burnt]." ${ }^{95}$ In the very last entry of the last section entitled "Memory of what has been preserved of the lamentations of Himyar and the location of their graves" ${ }^{96}$, al-Hamdānī gives very sparse information about Dhū Nuwās, ${ }^{97}$ and the only thing that can be said of value is that the poetry given here corresponds to that found in the entry on Dhū Nuwās in Kitāb al-tijānn. ${ }^{98}$

\section{al-Maqdisī}

The last source is not particularly difficult to place in terms of relationship, but it is difficult to place within one specific tradition. The Kitāb al-bad' wa-l-ta'rïkh of al-Maqdisī (fl. ca. 966) ${ }^{99}$ contains the story of Faymiyūn (corrupted in al-Maqdisī as Faymūn) according to the report of Ibn Ishāq on authority of Wahb. ${ }^{100}$ This account, however, contains sentences about the agreements between the Jews and Christians of Najrān not to betray each other, which is only found in the tafsir of al-Tabarī, and the account of the woman and her boy is added to the end of the story. ${ }^{101}$ The detail that Dhū Nuwās besieged (ḥassara/hasạara) Najrān is also found in Abū l-Faraj al-Ișfahānī. After the Ibn Isḥāq account, al-Maqdisī goes on to give another account of the same narrative, namely the Ibn al-Kalbī account also given by al-Ṭabarī in his history: "Apart from this (account), there has been told (another account) concerning the story of the Trench, and we have mentioned it in the Book of Good Qualities (Kitāb al-ma'ānī)." ${ }^{102}$ The most obvious hypothesis of relationship is that al-Maqdisĩ derives his material from al-Tabarī, both from the Tafsir and the history with possible influences from a tradition which ultimately informed al-Iṣfahānī.

91 Al-Hamdānī, al-Iklìl al-juz' al-thāmin, 2.

92 See my conjectural proposal in footnote 69 and figure 3 concerning which 'Dhū Nuwās-tradition' the fifth book of al-Iklil could have transmitted.

93 Al-Hamdānī, al-Iklìl al-juz' al-thāmin, 134-135.

94 Ibn Hishām, Sïra, I, 25.

95 Translation by Faris (1938, 80-81).

96 Dhikr mā hufiza min marāthì Hiimyar wa-mawāḍi` qubūrihum. Al-Hamdānī, Iklìl al-już’ al-thāmin, 176. This section is not included in Faris' translation.

97 Al-Hamdānī, al-Iklìl al-juz' al-thāmin, 226-227.

98 Ibn Hishām, Kitāb al-tijān, 301-302.

99 This work was first falsely attributed to Abū Zayd al-Balkhī, but this was later rectified by the editor in three of the prefaces, see $E I^{2}$, "al-Muțahhar b. Țāhir al-Maḳdisī." See Khalidi (1976, 1-12), for the theological profile of this text.

100 Al-Maqdisī, Kitāb al-bad' wa-l-ta'rīkh, III, 182.

101 Al-Maqdisī, Kitāb al-bad' wa-l-ta'rīkh, III, 183. See al-Ṭabarī, Jāmi' al-bayān 'an ta'wìl al-Qur'ān, XXX, 132. For translation, see footnote 67.

102 Al-Maqdisī, Kitāb al-bad' wa-l-ta'rīkh, III, 184. The work mentioned has unfortunately not survived. 


\section{The Mainstream tafsïr Tradition}

After the first generations of mufassirūn, a particular story seems to have won a place of pride in the collective memory concerning the aṣhāb al-ukhdūd (Q85:4) among authors writing exegetical works and works of hadith. An adaptation of the 'Abd Allāh ibn al-Thāmir story is found in most works of tafsir from the beginning of the ninth century onwards, and in a couple of hadith compilations. Two different recensions exist, the first of which exists in many 'subrecensions.'

\section{The Ṣuhayb Recension}

Disregarding the many small differences between the subrecensions, the overall narrative runs as follows: The royal sorcerer (or soothsayer) appeals to the king with a request to get an apprentice to whom he can pass on his knowledge and tradition. The apprentice boy has to commute past a monk's cell on his way to the sorcerer, and he is gradually converted to Islam by asking questions to the monk. The boy miraculously kills a creature which blocks the road and heals a blind man. After the king has killed the monk and the (formerly) blind man after having extracted intelligence about the boy, he tries to kill the boy as well. After two failed attempts (throwing him off a mountain and drowning him at sea), he finally succeeds with the help of the boy's own instructions: He has to crucify him and shoot him with arrows while acknowledging God. The people subsequently adopt the religion of the boy, so the king digs trenches and burns them. In some accounts, the story of the woman and her son is added. ${ }^{103}$

Compared to the story in Ibn Isḥāq, this 'tafsīr version' has been stripped of all contextual information. The name of neither the boy nor the king is given (no name occurs in the texts at all), there is no temporal indication and often even the location of Najrān is left out. This is probably deliberate, because it makes the story more flexible and lends itself more smoothly to interpretation. The primary sources for this recension are 'Abd al-Razzāq (d. 827), ${ }^{104} \mathrm{Ibn}$

103 See Cook (2008, 125-48), for translations and a discussion of this tradition. Cook has done a very good job in gathering a lot of the sources, but I am less surprised by the narrative than Cook is. He seems to read these stories (which he terms AU1 (the 'Abd Allāh story in Ibn Ishāa) and AU2 (the tafsìr and hadith versions)) in a harmonious way, where the readers of AU2 are supposed to have implicit knowledge of AU1, which should be read into the account of AU2. I think many of the points of confusion on Cook's part are quite easily explained as hagiographical tropes, especially if one, as Cook does, views these stories as originating in a Christian/Jewish milieu. The trope, for example, of the difficulty with which persecutors have killing the martyr, and that the martyr has to 'hand himself over' to his executioner, is found in the very earliest pieces of hagiography; see, e.g., The Martyrdom of Polycarp, §14-16, Musurillo (1972, 2-21). For an example closer in time and space to the Islamic story, consider the Martyrdom of Azqir: his perpetrators are only able to kill him once Azqīr permits his own execution with a Christian sword, thus sacrificing himself for his religion (Bausi 2017; Hirschberg 1939-1949, 326). The function of the sorcerer/soothsayer also seems to me quite clear (see Cook's comment on page 138, where he relegates the narrative function of the sorcerer as being merely "a schoolmaster," without any consequences for the story). The sorcerer wants an apprentice, so "I can teach him about this [sorcery], for I fear that when I die this knowledge will be cut off from you [the king] and that there will be no one who can teach it" (Cook 2008, 130). There is clearly a religious polemical reason for this statement. The boy, in effect, terminates the knowledge and tradition of sorcery by choosing the religion of the monk instead. In other words, the knowledge of sorcery/soothsaying will die with the sorcerer. 'Abd al-Razzāq, Kitāb al-muṣannaf, V, 420-423 (hadīth no. 9751). 
Hanbal (d. 855), ${ }^{105}$ al-Nasā'ì (d. 915), ${ }^{106}$ Muslim (d. 875) ${ }^{107}$ and al-Ṭabarī (d. 923). ${ }^{108}$ Each of these sources give slightly different versions through slightly different chains of transmission. They all ultimately transmit the story on authority of Șuhayb al-Rūmī (d. 658/9), who received it from Muhammad himself. Ibn Kathīr ${ }^{109}$ transmits the story through Ibn Hanbal, but tells us that al-Tirmidhī, al-Nasā'i and Muslim also transmit the story. 'Abd al-Razzāq, however, breaks off one chain earlier (at Thābit al-Bunānī (d. 744)), before the other sources diverge on different paths of transmission (from Hammād ibn Salama (d. 783)). This should also be manifest in the wording of the text, and this is indeed the case. Where all the other sources have one of the antagonists as sorcerer (sāhir), 'Abd al-Razzāq has a soothsayer ( $k a \bar{h} h i n$ ), and where the story of the woman and her son is extant in all the other sources, it is absent in 'Abd al-Razzāq. This is confirmed by those later authors who transmit from 'Abd al-Razzāq. ${ }^{110}$ Whereas David Cook views the story of the woman and her son as an added element, ${ }^{111}$ he does not draw the consequences of his study. It is reasonable to suggest that the story was added by Hammād ibn Salama, or at some point between him and Thābit, i.e., before 783 AD. The relationship between the Ibn Ishāq story and the version found in these tafsìr and hadith works is difficult to figure out. If we are to believe the isnāds in their entirety, then the latter version is not dependent on Ibn Ishạa, and the story has entered the Islamic tradition twice through two different sources, one Jewish-Yemenite (Muhammad ibn Ka'b) and one Christian-Syrian/Iraqi (Șuhayb al-Rūmī). ${ }^{112}$ However, it is possible that the first part of the isnād, Muhammad $\rightarrow$ Șuhayb $\rightarrow$ Ibn Abī Laylā, is fabricated, and that the story is, in fact, the one related from Muhammad ibn Kab (and preserved in the Sira), which subsequently was adapted for the purposes of tafsir and hadith. ${ }^{113}$ For a visualization of the reported chains of transmission, see figure 4.

\section{The Ibn 'Abbās Recension}

The Suhayb recension was in time reworked and clothed again in the explicit context of Najrān and the Martyrs. In Qiṣas al-'anbiy $\bar{a}^{\prime}$, al-Tha' labī (d. 1035) ${ }^{114}$ transmits a story related by 'Ațā' on authority of Ibn 'Abbās, where the king is called Yūsuf Dhū Nuwās ibn Shuraḥbīl, and the boy 'Abd Allāh ibn al-Sāmir (sic). The narrative has been smoothed out and certain vague points have been made more concrete (the creature blocking the road is, for example, a snake, the blind man is the king's nephew). The woman does not have one, but three children, who are all in turn thrown into the fire. This recension was clearly meant for entertainment

105 Ahmad ibn Hanbal, Musnad, XXXIX, 351-354 (hadīth no. 23931)

106 Al-Nasā'ì, Tafsìr, II, 509-513 (no. 681).

107 Muslim, Șahịh Muslim, VII, 401-405 (hadīth no. 3005; book 53, chapter 17).

108 Al-Ṭabarī, Jāmic al-bayān 'an ta'wìl al-Qur'ān, XXX, 133-134. Al-Tha'labī transmits from al-Ṭabarī. AlTha'labī, Al-Kashf wa-l-bayān, X, 168-169.

109 Ibn Kathīr, Tafsìr al-Qur'ān al-'azìim, VII, 255-256.

110 In particular, al-Tirmidhī (d. 892): al-Jāmi` al-kabìr, IV, 296-298 (ḥadìth no. 3655; book 45, chapter 76), and Yāqūt (d. 1229): Kitāb Mu'jam al-Buldān, IV, 754-755.

111 Cook $(2008,144)$.

112 Cook (2008, 130.132.144).

113 I have only included the most important and popular sources. The story of the boy and the monk became a must-have in tafsìr works; see the abridged version in al-Bayḍāwī (d. ca. 1286), Anwār al-tanzïl, II, 395. See also al-Zamakhskarī (d. 1144), Tafsīr al-kashshāf, II, 1594-1595. For further references, see Cook (2008, 125-48), who references numerous other sources.

114 Al-Tha'labī, Qiṣaș al-'anbiyā'), 436-438. See also Brinner's English translation (2002, 728-30). See Cook (2008, 140-41), where Cook discusses this recension, which he terms AU3. He does not seem to be aware that Ibn al-Athìr also transmits this recension, as he mentions this source at page 137 as quoting AU2. 


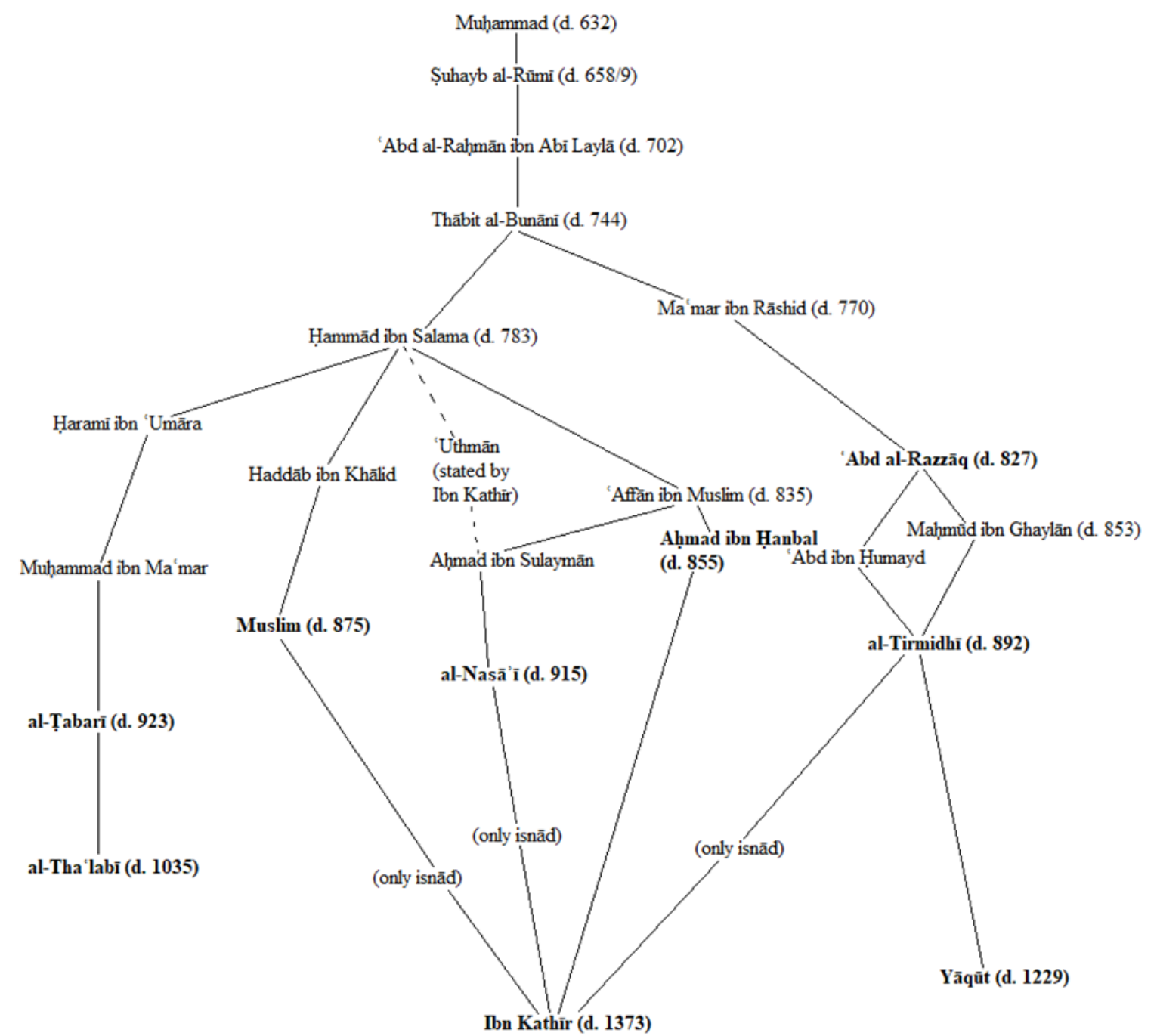

Figure 4 The Șuhayb recension of the tradition of the boy and the monk. 
purposes, smoothing out points of inconsistency in the narrative, and the contextualization makes it easier to visualize and imagine the story. Ibn al-Athīr (d. 1233) also transmits this version of the story on authority of Ibn 'Abbās. ${ }^{115}$

\section{Conclusions}

Through this survey of a wide variety of sources, the Islamic tradition of Dhū Nuwās and the Martyrs of Najrān appears a lot more diverse than what is usually the impression one gets from reading the paraphrases of scholars working within the history of late Antiquity and Religious Studies. Three main traditions within the historiographical genre have emerged, each with its own group of transmitters. The tradition of the anonymous work of The Kings of Himyar is probably the oldest tradition, going back to Wahb ibn Munabbih, if not further. In the middle of the eighth century, Ibn Ishāq likely used this work to structure the pre-Islamic section (mubtadi') of his biography of the Prophet. In this text, the Martyrs of Najrān are said to adhere to 'the religion of Jesus,' a pure monotheistic kind of Christianity, the followers of which Muhammad would later encounter in Medina, albeit by then adherents of a corrupted Christianity (al-nașāniyya). Another tradition transmitted primarily by Ibn al-Kalbī exhibits many differences from this key text, among them a difference in motive. In Ibn al-Kalbī, Dhū Nuwās seems to be motivated by revenge during a civil strife between Christians and Jews. Being a Jew himself, he of course sides with the Jewish party, and thus invites the Axumite kingdom to the escalating conflict. However, in the genres with direct legal implications, i.e., tafsir and hadith, the Martyrs of Najrān are often appropriated as 'proto-Muslims.' Both in the very early stages of Qur'ānic exegesis, and in the later story of the boy and the monk, the religious nomenclature is entirely Islamic in character. Occasionally, they are identified as 'the Christians of Yemen,' but always in juxtaposition with terms such as 'believers,' 'monotheists,' or 'Muslims.' It is hard to systematize exactly how the different Muslim writers have dealt with and incorporated the Martyrs of Najrān into their respective historiographical, exegetical and legal narratives. Nevertheless, in the following table in figure $5 \mathrm{I}$ have, in order to give some overview, made a crude distinction between 1) integrating the Christian Martyrs of Najrān as Christians, adherents of Christianity, i.e., the religion, which the writers themselves would have been familiar with through interaction with their contemporaries, 2) assimilating the Martyrs to the prophetic/revelatory narrative of Islam, being adherents of the 'unspoiled' monotheistic religion of God's prophet, Jesus, which later was corrupted into the schismatic religion, Christianity, and 3) appropriating the Martyrs as Muslims proper using only Islamic lingo as 'believers,' 'Muslims,' followers of the laws of Islam, etc., by which the writer establishes a religious identification between the Martyrs and himself and his recipients.

Interest in the religion of the perpetrator, Dhū Nuwās, falls along the same lines as that of the Martyrs. Whereas the 'appropriating/identifying' sources of tafsir and hadith are not interested in the specific religion of the anonymous king-only that he tries to force the believers to apostatize from 'Islam'-many of the 'integrating' and 'assimilating' sources of historiographical character are interested in the Jewish religion of Dhū Nuwās. Two writers, al-Dīnawari and Hamza, even add stories about his conversion to Judaism to their narratives. Thus, the sources also take different approaches to the interreligious elements of the narrative. Some authors, such as the two just mentioned, and for example Ibn al-Kalbī, are interested in the specific religious factions, and highlight this dimension of the narrative accordingly

115 Ibn al-Athīr, Al-Kāmil, I, 429-431. 


\begin{tabular}{|c|c|c|c|}
\hline & Integration & Assimilation & Appropriation/Identification \\
\hline $\begin{array}{l}\text { Religious } \\
\text { vocabulary used in } \\
\text { the sources: }\end{array}$ & $\begin{array}{l}\text { Christians (nașārā), } \\
\text { Christianity (al- } \\
\text { nașrāniyya) }\end{array}$ & $\begin{array}{l}\text { Monotheists } \\
\text { ( } m u w a h h i d \bar{u} n \text { ), religion of } \\
\text { Jesus ( } d \bar{i} n \bar{I} \bar{I} \bar{a}) \text {, religion of } \\
\text { Christ (din al-Masih })\end{array}$ & $\begin{array}{l}\text { Muslims (muslimūn), believers } \\
\text { (mu'minūn), the laws of Islam } \\
\text { (sharā' } i^{\prime} \text { al-islām) }\end{array}$ \\
\hline $\begin{array}{l}\text { Earliest } t a f s \bar{i} r \\
\text { traditions }\end{array}$ & & & $\begin{array}{l}\text { Ibn 'Abbās-traditions; } \\
\text { al-Ḍaḥhāk; } \\
\text { Muqātil; } \\
\text { Mujāhid }\end{array}$ \\
\hline $\begin{array}{l}\text { The Kings of } \\
\text { Himyar }\end{array}$ & $\begin{array}{l}\text { Ibn Hishām }(K . \text { al-tījāan }) \text {; } \\
\text { Ibn Qutayba; } \\
\text { Hamza; } \\
\text { Ibn Sa'īd }\end{array}$ & al-Mas' ūdī & \\
\hline Ibn Isḥāq tradition & $\begin{array}{l}\text { Abū l-Faraj al-Ișfahānī } \\
\text { (transmitted through ibn } \\
\text { al-Kalbī); } \\
\text { Ibn Habīb? (mixed } \\
\text { vocabulary, transmitted } \\
\text { through Ibn al-Kalbī) }\end{array}$ & $\begin{array}{l}\text { Ibn Ishāq (as transmitted } \\
\text { in Ibn Hishām's Sïra and } \\
\text { al-Țabarī's Ta'rikh }) \text {; } \\
\text { al-Ya'qūbī; } \\
\text { Ibn Habīib? }\end{array}$ & $\begin{array}{l}\text { Muhammad ibn Ka'b ('Abd } \\
\text { Allāh ibn al-Thāmir-story as } \\
\text { transmitted in Ibn Ishāāq) }\end{array}$ \\
\hline $\begin{array}{l}\text { Ibn al-Kalbī } \\
\text { tradition }\end{array}$ & $\begin{array}{l}\text { Ibn al-Kalbī (as } \\
\text { transmitted in al-T abarī's } \\
\text { Ta'rikhh); } \\
\text { Nashwān }\end{array}$ & & \\
\hline Misc. sources & $\begin{array}{l}\text { al-Dīnawarī? (mixed } \\
\text { vocabulary, transmitted } \\
\text { through Ibn Ishāq?) }\end{array}$ & al-Dīnawarī? & \\
\hline $\begin{array}{l}\text { Mainstream tafsir } \\
\text { tradition }\end{array}$ & & & All the sources \\
\hline
\end{tabular}

Figure 5 Table of the sources' attitudes to and incorporation of the Martyrs of Najran. 
by explicating the exact reason for Dhū Nuwās' aggression. Others are primarily interested in the Martyrs as pure monotheists and pre-Islamic adherents of the true religion, and in these cases the religion of Dhū Nuwās is downplayed-he is most often explicitly Jewish, but it is mentioned in passing-such as in al-Mas'ū ūi and Ibn Isḥāq. The tafsìr sources are not interested in these matters, as they have alleviated the original religious categories for the purposes of Islamic edification.

The reconstruction, sometimes by conjecture, of the relationships between the different sources which I have put forth in the present contribution is by no means bulletproof, but I hope at least to have fertilized the ground for further study of the Islamic literary works which deal with this intriguing set of events in history, not just as containers for earlier Christian material, but as interesting religious expressions with their own set of agendas.

\section{Primary Sources}

'Abd al-Razzāq al-Ṣan'ānī Kitāb al-muṣannaf: ed. Ḥabīb al-Raḥmān al-A'ẓamī, al-Muṣannaf, 11 vols. + index, Beirut, 1970-83 [V, 420-423]

Abū 1-Faraj al-Ișfahānī Kitāb al-aghānī: ed. [various editors], Kitāb al-aghānī, 24 vols., Dar al-kutub, Egypt, 1928-94 [XVII, 303-304]

Abū l-Fidā' Mukhtașar ta'rīkh al-bashar: ed. and transl. Heinrich Fleischer, Abulfedae historia anteislamica, Leipzig, 1831 [118]

Al-Bayḍāwī Anwār al-tanzīl wa-asrār al-ta'wïl: ed. Heinrich Fleischer, Beidhawii commentarius in coranum, 2 vols., 1846-8 (reprint Osnabrück 1968) [II, 395]

Al-Ḍaḥhāāk ibn Muzāḥim Tafsïr: ed. Muḥammad Shukrī Aḥmad al-Zāwiyyatī, Tafsìr alDahhạāk, 2 vols., Cairo, 1999 [II, 950]

Al-Dīnawarī Kitāb al-akhbār al-țiwāl: ed. Vladimir Guirgass, Kitāb al-akhbār al-țiwāl, Leiden, 1888 [62-63]

Al-Hamdānī al-Iklìl al-juz' al-thāmin: ed. Nabīh Amīn Fāris, al-Iklìl al-juz' al-thāmin, Beirut \& Șan'ā', 1940 [2+134-135+226-227]

Ḥamza al-Iṣfahānī Ta’rīkh: ed. \& transl. I. M. E. Gottwaldt, Hamzae Ispahanensis annalium libri X, 2 vols., St. Petersburg \& Leipzig, 1844 [I, 133-134]; ed. [anon.], Ta'rïkh sini mulūk wa-l-arḍ wa-l- 'anbiyā', Beirut, (1961) [105-106]

Ibn al-Athīr Al-Kāmil fi l-ta'rïkh: ed. Carolus Johannes Tornberg, Ibn-el-Athiri chronicon quod perfectissimum inscribitur, 12 vols., Leiden, 1853-67 [edition typeset anew in Beirut 1965-6 as Ibn al-Athïr al-Kämil fi'l-ta'rïkh] [Beirut edition: I, 425-432]

Ibn Ḥabīb Kitāb al-muhabbar: ed. Ilse Lichtenstädter, Kitāb al-muhabbar, Hyderabad, 1942 [368]

Ibn Ḥanbal Musnad: ed. Shu'ayb al-Arna'ūṭ (chief editor), Musnad al-Imām Aḥmad ibn Hanbal, 50 vols., Mu'assasa al-Risāla, Beirut, 1995-2001 [XXXIX, 351-354]

Ibn Hishām Sïra: ed. Ferdinand Wüstenfeld, Das Leben Muhammed's nach Muhammed Ibn Ishâk, 2 vols., Göttingen, 1858 [I, 20-26] 
Ibn Hishām Kitāb al-tijjān: ed. [anon.], Kitāb al-tijjān fi mulūk Himyar, Hyderabad, 1928 [301302]

Ibn Kathīr Al-bidāya wa-l-nihāya: ed. 'Abd Allāh al-Turkī, Al-bidāya wa-l-nihāya, 20 vols., Giza, 1997-9 [III, 133-136]

Ibn Kathīr Tafsïr al-Qur'ān al-'azìm: ed. [anon.], Tafsïr al-Qur’ān al-'ažim, 7 vols., Dar al-Fikr, Beirut, 1966 ( $3^{\text {rd }}$ edition, 1970) [VII, 255-261]

Ibn Khaldūn Ta'rïkh: ed. Suhayl Zakkār, Muqaddima + Ta'rïkh ibn Khaldūn, 7 vols., Dar alFikr, Beirut, 2000-1 [II, 68-69]

Ibn al-Mujāwir Tārïkh al-mustabṣir: ed. Oscar Löfgren, Descriptio arabiae meridionalis, 2 vols., Brill, Leiden, 1951-4 [I, 95-96 + II, 209]

Ibn al-Nadīm Fihrist: ed. Ayman Fu'ād Sayyid, Kitāb al-fihrist, 2 vols., al-Furqān, London, $2^{\text {nd }}$ edition, 2014.

Ibn Qutayba Kitāb al-ma'ārif: ed. Ferdinand Wüstenfeld, Ibn Coteiba's Handbuch der Geschichte, Göttingen, 1850 [311-312]

Ibn Sa'īd al-Maghribī Nashwat al-țarab fi ta'rīkh jāhiliyyat al-'arab: ed. Nașrat 'Abd alRaḥmān, Nashwat al-țarab fi ta'rīkh jāhiliyyat al-`arab, 2 vols., Amman, 1982 [I, 156]

Ibn Wahab al-Dīnawarī Tafsïr: ed. Aḥmad Farīd, Tafsïr ibn Wahab, 2 vols., Beirut, 2003 [II, 487-488]

Al-Maqdisī Kitāb al-bad' wa-l-ta'rỉkh: ed. Clément Huart, Le livre de la création et de l'histoire, 6 vols., Paris, 1899-1919 [III, 182-185]

Al-Mas' $\overline{\mathbf{u}} \mathbf{i} \mathbf{i}$ Murūj al-dhahab: ed. \& revised, C. Barbier de Meynard \& P. de Courteille \& Charles Pellat, Ma'ūdì: Les prairies d'or, 7 vols., Beyrouth, 1966-1979 [I, 74-75 + II, 199200]

Mujāhid ibn Jabr Tafsīr: ed. Muhammad 'Abd al-Salām Abū 1-Nīl, Tafsīr al-Imām Mujāhid ibn Jabr, Giza, 1989 [718]

Muqātil ibn Sulaymān Tafsìr: ed. 'Abd Allāh Muhammad, Tafsīr Muqātil ibn Sulaymān, 4 vols., Beirut, 2002 [IV, 647-648]

Muslim Șaḥịh Muslim: ed. Hāfiz Abū Tāhir Zubayr 'Ali Za'i, tr. Nasiruddin al-Khattab, English Translation of Sahîh Muslim, 7 vols., Dar as-Salam, Riyadh, 2007 [VII, 401-405]

Al-Nasā'ī Tafsìr: ed. [anon.], Tafsïr al-Nasā'ī, 2 vols., Beirut, 1990 [II, 509-513]

Nashwān ibn Sa'īd al-Ḥimyarī Shams al-'ulūm: ed. 'Aẓīmuddīn Aḥmad, Die auf Südarabien bezüglichen Angaben Našwān's im Šams al-‘ulūm, Leiden \& London, 1916 [15 + 31 + 106$107+116]$

Nashwān ibn Sa'īd al-Ḥimyarī Mulūk Hiimyar wa-'aqyāl al-Yaman: ed. 'Alī ibn Ishmā̄īl alMu'tīd \& Ishmā'īl ibn Aḥmad al-Jarāfī, Mulūk Himyar wa-'aqyāl al-Yaman, Beirut, 1978 [147-149] 
Al-Qazwīnī Kitāb āthār al-bilād: ed. Ferdinand Wüstenfeld, el-Cazwini's Kosmographie, 2 vols., Göttingen, 1848-9 [II, 84]

Al-Ṭabarī Ta'rïkh: ed. M. J. de Goeje et al., Annales quos scripsit Abu Djafar Mohammed ibn Djarir at- Tabari, 15 vols., Leiden, 1879-1901 (reprint 1964) [II, 919-930]

Al-Ṭabarī Jāmi' al-bayān 'an ta'wìl al-Qur'ān: ed. [anon.], Jāmi' al-bayān 'an ta'wīl al-Qur'ān, 30 vols., Mostafa Bab Halabi \& Sons Press, 1968 [XXX, 132-134]

Al-Tha'labì Qișaș al-anbiyā’: ed. [anon.], Qiṣaș al-anbiyā̄', Mostafa Bab Halabi \& Sons Press, 1954 [436-439]

Al-Tha'labī Al-Kashf wa-l-bayān: ed. al-Imam Abī Muhammad ibn 'Āshwar, al-Kashf wa-lbayān, 10 vols., Beirut, 2002 [X, 168-169]

Al-Tirmidhī al-Jāmi` al-kabïr: ed. [anon.], Sunan al-Tïrmidhī wa-huwa al-Jāmi` al-kabìr, 4 vols. + index, Dār al-Ta'ṣīl, Cairo, 2nd edition, 2016 [IV, 296-298]

Al-Ya'qūbī Ta'rīkh: ed. M. Th. Houtsma, Ibn-Wādhih qui dicitur al-Ja'qubī historiae, 2 vols., Leiden, 1883 (reprint 1969) [I, 225-226]

Yāqūt Kitāb mu'jam al-buldān: ed. Ferdinand Wüstenfeld, Jacut's geographisches Wörterbuch, 6 vols., Leipzig, 1866-73 [IV, 752-757]

Al-Zamakhsharī Tafsïr al-kashshāf: ed. William Nassau Lees, The Kashshaf 'an Haqaiq altanzil, 2 vols., Calcutta, 1856 [II, 1594-1595]

\section{Encyclopaedia of Islam Entries}

$\mathrm{EI}^{2}:$ Encyclopaedia of Islam, second edition

“al-Hamdānī”, by Oscar Löfgren.

"Ḥamza al-Iṣfahānī”, by Franz Rosenthal.

"Ibn Sharya", by Franz Rosenthal.

"al-Mas'ūdī", by Charles Pellat.

“al-Muțahhar b. Țāhir al-Maḳdisī”, by the editors (Ed.).

\section{References}

Adang, Camilla. 2006. "The Chronology of the Israelites According to Hamza Al-Ișfahānī." Jerusalem Studies in Arabic and Islam 32: 286-310.

Arneson, Hans, Emanuel Fiano, Christine Luckritz Marquis, and Kyle Smith. 2010. The History of the Great Deeds of Bishop Paul of Qentos and Priest John of Edessa. Piscataway: Gorgias Press.

Bausi, Alessandro. 2017. "Il Gadla 'Azqir." Adamantius 23.

Bausi, Alessandro, and Alessandro Gori. 2006. Tradizioni orientali del "Martirio di Areta". Florence: Dipartimento di Linguistica. 
Beeston, A. F. L. 1985. "Two Bi'r Himā Inscriptions Re-Examined." Bulletin of the School of Oriental and African Studies 48 (1): 42-52.

—. 1989. "The Chain of Al-Mandab." In On Both Sides of Al-Mandab, edited by Ulla Ehrensvärd and Christopher Toll. Stockholm: Svenska Forskninginstitutet i Istanbul.

Berg, Herbert. 2011. "The Isnād and the Production of Cultural Memory: Ibn 'Abbās as a Case Study." Numen 58: 259-83.

Binggeli, André. 2007. "Les versions orientales du Martyre de Saint Aréthas et de ses compagnons." In Le Martyre de Saint Aréthas et de ses compagnons, edited by Marina Detoraki, 163-77. BHG 166. Paris: ssociation des amis du Centre d'Histoire et Civilisation de Byzance.

Bonner, Michael Richard Jackson. 2014. "An Historiographical Study of Abū Ḥanīfa Aḥmad ibn Dāwūd ibn Wanand al-Dīnawarī’s Kitāb al-Aḩbār al-Ṭiwāl.” PhD diss., Oxford: University of Oxford.

- 2015. Al-Dīnawarī's Kitāb al-ahbār al-țiwāl: An Historiographical Study of Sasanian Iran. Leuven: Groupe pour l'Étude de la Civilisation du Moyen-Orient.

Bosworth, C. E. 1999. The History of Al-Ṭabarī. Volume V-the Sāsānids, the Byzantines, the Lakhmids, and Yemen. New York: SUNY Press.

Bowersock, Glen W. 2013. The Throne of Adulis: Red Sea Wars on the Eve of Islam. Oxford: Oxford University Press.

Brinner, William M. 2002. 'Arā’is al-majālis fi qișas al-anbiyā', or: Lives of the Prophets. Leiden: Brill.

Cook, David. 2008. "The Așhāb al-Ukhdūd: History and Hadìth in a Martyrological Sequence." Jerusalem Studies in Arabic and Islam 34: 125-48.

Crosby, Elise W. 2007. The History, Poetry, and Genealogy of the Yemen. The Akhbar of Abid B. Sharya Al-Jurhumi. Piscataway: Gorgias Press.

Detoraki, Marina. 2007. Le martyre de saint Aréthas et de ses compagnons. BHG 166. Paris: Association des amis du Centre d'histoire et civilisation de Byzance.

Donner, Fred McGraw. 1998. Narratives of Islamic Origins: The Beginning of Islamic Historical Writing. Princeton: The Darwin Press.

Faris, Nabih Amin. 1938. The Antiquities of South Arabia Being a Translation from the Arabic with Linguistic, Geographic, and Historic Notes of the Eighth Book of Al-Hamdāni's Al-Iklil. Princeton: Princeton University Press.

Fell, Winand. 1881. "Die Christenverfolgung in Südarabien und die himjaritisch-äthiopischen Kriege nach abessinischer Überlieferung." Zeitschrift der Deutschen Morgenländischen Gesellschaft 35: 1-74.

Fleischhammer, Manfred. 2004. Die Quellen des Kitāb al-Ag̀̄āni. Wiesbaden: Harrassowitz Verlag.

Goldfeld, Isaiah. 1981. "The Tafsīr of Abdallah B. 'Abbās.” Der Islam 58: 125-35.

Guidi, Ignazio. 1881. "La lettera di Simeone vescovo di Bêth-Arśâm sopra i martiri omeriti." Atti della R. Accademia dei Lincei III (7): 471-515.

Guillaume, Alfred. 1955. The Life of Muhammad. A Translation of Ishāa's Sïrat Rasūl Allāh. Oxford: Oxford University Press.

Heer, F. Justus. 1898. Die historischen und geographischen Quellen in Jāqūt's Geographischem Wörterbuch. Strassburg: Karl J. Trübner.

Hirschberg, J. W. 1939-1949. "Nestorian Sources of North-Arabian Traditions on the Establishment and Persecution of Christianity in Yemen." Rocznik Orientalistyczny 15: 321-38. 
Jeffery, Arthur. 1946. "Christianity in South Arabia." The Moslem World 36: 193-216.

Khalidi, Tarif. 1975. Islamic Historiography: The Histories of Mas'udi. New York: State University of New York Press.

— 1976. "Mu'tazilite Historiography: Maqdisī's Kitāb Al-Bad’ Wa'l-Ta'rīkh." Journal of Near Eastern Studies 35 (1): 1-12.

Khoury, Raif Georges. 1972. Wahb b. Munabbih. Teil 1. Der Heidelberger Papyrus PSR Heid Arab 23. Wiesbaden: Harrassowitz Verlag.

Kilpatrick, Hilary. 2003. Making the Great Book of Songs: Compilation and the Author's Craft in Abû L-Faraj Al-Işbahânî's Kitâb Al-Aghânî. London \& New York: Routledge.

Koç, Mehmet Akif. 2008. "A Comparasion of the References to Muqātil B. Sulaymān (150/767) in the Exegesis of Al-Tha'labī (427/1036) with Muqātil's Own Exegesis." Journal of Semitic Studies 53 (1): 69-101.

Kremer, Alfred von. 1866. Über die südarabische Sage. Leipzig: F.A. Brockhaus.

Lane, Edward William. 1863. An Arabic-English Lexicon. Vol. 8. London: Williams and Norgate. La Spisa, Paolo. 2010. "Les versions arabes du Martyre de Saint Aréthas." In Juifs et chrétiens en arabie aux Ve et VIe siècles: regards croisés sur les sources, edited by Joëlle Beaucamp, Françoise Briquel-Chatonnet, and Christian Julien Robin, 227-38. Paris: Association des amis du Centre d'Histoire et Civilisation de Byzance.

— 2017. "Martirio e rappresaglia nell'Arabia meridionale dei secoli V e VI: uno sguardo sinottico tra fonti islamiche e cristiane." Adamantius 23: 318-40.

Lecomte, Gérard. 1965. Ibn Qutayba (mort en 276/889): L'homme, son oeuvre, ses idées. Damascus: Institut Français de Damas.

Lichtenstädter, Ilse. 1939. "Muḥammad Ibn Habîb and His Kitâb Al-Muhabbar"." Journal of the Royal Asiatic Society I (January): 1-27.

Mazuz, Haggai. 2016. "Possible Midrashic Sources in Muqātil B. Sulaymān's Tafsīr.” Journal of Semitic Studies 61 (2): 497-505.

Moberg, Axel. 1924. The Book of the Himyarites: Fragments of a Hitherto Unknown Syriac Work. Lund: C.W.K. Gleerup.

— 1925. "Kristna legender i Tabaris berättelser om kristendomen i Nagran." In Studier tilegnede professor, dr. phil. \& theol. Frants Buhl, edited by Johannes Jacobsen, phil., Frants Buhl, and Johannes Jacobsen, 137-50 , Copenhagen: V. Pios Boghandel. . 1930. Über einige christliche Legenden in der islamischen Tradition. Lund: Håkan Ohlssons Buchdruckeri.

Munt, Harry, Touraj Daryaee, Omar Edaibat, Robert Hoyland, and Isabel Toral-Niehoff. 2015. "Arabic and Persian Sources for Pre-Islamic Arabia." In Arabs and Empires Before Islam, edited by Greg Fischer, 434-500. Oxford: Oxford University Press.

Musurillo, Herbert. 1972. Acts of the Christian Martyrs. Oxford: Oxford University Press.

Nickel, Gordon. 2006. “'We Will Make Peace with You': The Christians of Najrān in Muqātil's Tafsīr." Collectanea Christiana Orientalia 3: 171-88.

Power, Timothy. 2012. The Red Sea from Byzantium to the Caliphate AD 500-1000. Cairo \& New York: The American University in Cairo Press.

Pregill, Michael. 2008. "Isrā'īliyyāt, Myth, and Pseudepigraphy: Wahb B. Munabbih and the Early Islamic Versions of the Fall of Adam and Eve." Jerusalem Studies in Arabic and Islam 34: 215-84.

Prémare, Alfred-Louis de. 2005. "Wahb B. Munabbih, une figure singulière du premier islam." Annales. Histoire, Sciences Sociales 60 (3): 531-49. 
Retsö, Jan. 2005-2006. "Wahb B. Munabbih, the Kitāb Al-Tījān and the History of Yemen." Arabia 3: 227-36.

Rippin, Andrew. 1994. "Tafsï Ibn 'Abbās and Criteria for Dating Early Tafïr Texts." Jerusalem Studies in Arabic and Islam 18: 38-83.

Robin, Christian Julien. 2004. "Himyar et Israël." Comptes rendus des séances de l'Académie des Inscriptions et Belles-Lettres 148 (2): 831-908.

—. 2008. "Joseph, dernier roi de Ḥimyar (de 522 à 525, ou une de années suivantes)." Jerusalem Studies in Arabic and Islam 34: 1-124.

— 2010. "Nagrān vers l'époque du massacre: Notes sur l'histoire politique, économique et institutionelle et sur l'introduction du christianisme (avec un réexamen du Martyre d'Azqīr)." In Juifs et chrétiens en arabie aux ve et vie siècles: regards croisés sur les sources, edited by Joëlle Beaucamp, Françoise Briquel-Chatonnet, and Christian Julien Robin, 39-106. Paris: Association des amis du Centre d'Histoire et Civilisation de Byzance.

—. 2012. "Arabia and Ethiopia." In The Oxford Handbook of Late Antiquity, edited by Scott Fitzgerald Johnson, 247-332. Oxford: Oxford University Press.

— 2015. "Himyar, Aksūm, and Arabia Deserta in Late Antiquity: The Epigraphic Evidence." In Arabs and Empires Before Islam, edited by Greg Fischer, 127-71. Oxford: Oxford University Press.

Rosenthal, Franz. 1968. A History of Muslim Historiography. Leiden: Brill.

Rubin, Zeev. 2000. "Judaism and Rahmanite Monotheism in the Himyarite Kingdom in the Fifth Century." In Israel and Ishmael: Studies in Muslim Jewish Relations, edited by Tudor Parfitt, 32-51, Richmond, Surrey: St. Martin's Press.

—. 2008. "Islamic Traditions on the Sāsānian Conquest of the Himyarite Realm." Der Islam 84: 185-99.

. 2010. "Some Observations on Islamic Traditions Concerning the Persecution of Christians in Najrān." In Juifs et Chrétiens En Arabie Aux Ve et Vie Siècles: Regards Croisés Sur Les Sources, edited by Joëlle Beaucamp, Françoise Briquel-Chatonnet, and Christian Julien Robin, 239-40. Paris: Association des amis du Centre d'Histoire et Civilisation de Byzance.

Shahîd, Irfan. 1971. The Martyrs of Najrân: New Documents. Subsidia Hagiographica 49. Bruxelles: Société des bollandistes.

—. 1979. "Byzantium in South Arabia." Dumbarton Oaks Papers 33: 23-94.

- 1984. Byzantium and the Arabs in the Fourth Century. Washington D.C: Dumbarton Oaks Research Library and Collection.

-1989. Byzantium and the Arabs in the Fifth Century. Washington D.C.: Dumbarton Oaks Research Library and Collection.

Silverstein, Adam. 2019. "Who Are the Aṣhāb Al-Ukhdūd? Q 85:4-10 in Near Eastern Context." Der Islam 96 (2): 281-323.

Sizgorich, Thomas. 2010. "'Become Infidels or We Will Throw You into the Fire': The Martyrs of Najrān in Early Muslim Historiography, Hagiography, and Qur’ānic Exegesis." In Writing "True Stories": Historians and Hagiographers in the Late Antique and Medieval Near East, edited by Arietta Papaconstantinou, 125-47. Turnhout: Brepols.

Smith, G. Rex. 2008. A Traveller in Thirteenth-Century Arabia: Ibn Al-Mujāwir's Tārïkh AlMustabșir. London: Ashgate.

Taylor, David G. K. 2010. "A Stylistic Comparison of the Syriac Himyarite Martyr Texts Attributed to Simeon of Beth Arsham." In Juifs et Chrétiens En Arabie Aux Ve et Vie Siècles: 
Regards Croisés Sur Les Sources, edited by Joëlle Beaucamp, Françoise Briquel-Chatonnet, and Christian Julien Robin, 143-76. Paris: Association des amis du Centre d'Histoire et Civilisation de Byzance.

Tayyara, Abed el-Rahman. 2018. "Ibn Habīb’s Kitāb Al-Muḥabbar and Its Place in Early Islamic Historical Writing." Journal of Islamic Studies 29 (3): 392-416.

Toft, Lasse Løvlund. forthcoming. "Najran in the Sira: Narrative Roles and Muslim Attitudes Towards the South Arabian Christians." Semitica et Classica 14.

Versteegh, Kees. 1990. "Grammar and Exegesis: The Origins of Kufan Grammar and the Tafsīr Muqātil." Der Islam 67: 206-42.

. 2011. "The Name of the Ant and the Call to Holy War: Al-Ḍaḥhāk Ibn Muzāhim's Commentary on the Qur'ān." In Transmission and Dynamics of the Textual Sources of Islam: A Collection of Studies Presented to Harald Motzki, edited by Nicolet Boekhoff-van der Voort, Kees Versteegh, and Joas Wagemakers, 279-99. Leiden: Brill. 